\title{
KUTATÁS
}

\section{PRAKFALVI ENDRE}

\section{A MAGYAR KIRÁLYI PÉNZÜGYMINISZTÉRIUM EGYKORI PALOTÁJA A BUDAI VÁRBAN*}

\author{
Tekintetességed által tervezett Góth stílü munka, mely jelenkor \\ legnehezebb vívmányai közé tartozik, de a legszebb, ... az alapkőtöl (Grundstein) \\ egész a kémény fedlapig szorgalmunk és és ügyességünk által [épült]. ${ }^{1}$
}

Fellner Sándor (Pest, 1857. január 22. - Budapest 1944. november) a Reáltanoda utcai Főreáliskola elvégzése után ${ }^{2}$ a József Müegyetemen - a Cs. K. Joseph Polytechnikumot az 1871/72. tanévben ugyan egyetemi rangra emelték, de azokban az években valójában még nem egyetemi szervezetű intézmény volt - tizenöt évesen megkezdett tanulmányait ${ }^{3}$ a neoklasszicizmus stílusában tervező Theophil Hansen növendékeként folytatta Bécsben, a Képzőmüvészeti Akadémián 1873-1876 között. A császárvárosba mint a magyar művészeti ösztöndíj nyertese jutott el. A stipendiumot a budai várépítési alapból Ferenc József hozta létre; három évig évi 420 koronát kapott egy-egy festő, szobrász és építész diák. ${ }^{4}$ Budapestre 1879-elején tért vissza, már Párizsból, ${ }^{5}$ ahol Charles Garnier irodájában a francia reneszánsz és barokk formanyelvet sajátíthatta el, s rajzolni és festeni tanult Zichy Mihály mütermében. ${ }^{6}$ Budapesten az 1880-as, '90-es években megtervezte Bulyovszky Gyuláné Andrássy út 124. villáját (1883), a Talmud Egylet Hajós utcai zsinagógáját (ma Vasvári Pál utca, 1885), majd a Zsigmond utcai zsinagógát (Frankel Leó utca, 1888). Tisza Lajos - Szeged városát az árvíz után (1879) újjáépító kormánybiztos - számára átalakította a Hold utca 21. szám alatti házat (1889/90). A kilencvenes évek közepén pedig megépítette a Papnövelde u. 10. szám alatti bérpalotát (1894/96, építtető Palikucsevny Arthur), valamint a Somogy megyei Felsősegesden a Széchenyi-kastélyt (1903). Befektetésként épített saját házai: Kálmán Imre utca 17. (1890-91), Baross utca 41. (1895), Horváth Mihály tér 2. (1898), Podmaniczky utca 71. (1898). ${ }^{7}$ (1. kép)

Lukács László, ${ }^{8}$ a Széll-kormány pénzügyminisztere 1899 nyarán személyesen bízta meg az építészt, hogy a „Pénzügyminisztérium új palotájának beosztásával, elhelyezésével" foglalkozzon. A minisztérium több épületben működött a budai vár és a Víziváros területén. Fellner saját szavai szerint a „közhivatalok elhelyezésének kérdését évek óta” tanulmányozta ekkor már. Az új épület „program terjedelme" azonban előmunkálatokat tett szükségessé. Graetzi Graenzenstein Béla ${ }^{9}$ államtitkár kísérőjeként is tanulmányozta Németország, Franciaország és Anglia „legújabb közhivatali épülete$i t^{\prime \prime}{ }^{10}$ Egyelőre nem ismeretes forráshely vagy irodalmi hivatkozás Fellner közhivatalok elhelyezésére vonatkozó munkásságáról. Ha volt is írásban lefektetett tervezési program, az az őrzési helyeken nem lelhető fel. ${ }^{11}$ Funkcionális szempontból Fellner megoldása az ún. cella rendszerben - „minden tisztviselő, aki fogalmazással foglalkozik, külön helyiséget kapjon” - történt; a "hivatalos szobák” egymástól elszeparáltak, és csupán az oldalfolyosókról közelíthetők meg. Az irodák méretezése, az épületszárnyakban történő elhelyezése pedig öszszefüggésben állt a feladat súlyával és a hivatalnok pozíciójával. A kormány 1900. december 31-én, a XIX. század utolsó napján, az eredeti vázlatok némi módosítása után elfogadta a terveket. ${ }^{12}$ (2. kép)

Az 1900. évi XXXIV. tc. a Pénzügyminisztérium elhelyezésére négymillió Koronát irányzott elő az Országház utca-Fortuna köz-Iskola tér-Pázmány utca határolta telektömbön. Kikötés volt, hogy az Egyetemi Nyomda egyelőre maradjon meg az Iskola téri épületében. ${ }^{13}$ A miniszter 15. számú, 1901. január 3-i rendelete alapján létesített Építési Bizottság - a továbbiakban: ÉB - elnöke Graenzenstein Béla, a Pénzügyminisztérium államtitkára lett. Az ÉB 1901. január 6-án tartotta meg alakuló ülését, melynek keretében az elnök bemutatta a Fellner készítette „,skizzeket”, s megbízták a részlettervek elkészítésével. ${ }^{14}$ 
A Vállalkozók Lapja 1901 év elején a Nemzetgazdasági Szemléből idézett, mely szerint egy bécsi újságban hirdetés jelent meg; Budapesti építész-iroda hosszabb időn át foglalkoztat „tüchtige Gothiker, flotte Zeichner" alkalmazottakat. A lap utánajárt a dolognak, s kiderült, hogy az iroda „nem másé, mint Fellner Sándor építészé, akiről a múlt héten azon réven írtak a lapok, hogy a pénzügyminisztérium új palotájának tervezését pályázat nélkül - méltánytalan, a közérdeket bántó módon - magához kaparintotta [...] Fellner úr jó német, (aki ma sem tud magyarul) jó testvéreit tőle telhetőleg támogatja...". ${ }^{15}$ Zobel Lajos pénzügyi tanácsos, építész - a még öntöttvas oszlopos támaszrendszerű Óbudai dohánygyár tervezője (1892) - műszaki szempontú bírálatot adott az ÉB számára az 1901. január 21-én tartott ülésen Fellner Sándor tervezetéről, amely a beékelődött Egyetemi Nyomda épségben tartása mellett „kontempláltatott”. Összességében azt állapította meg, hogy a „kedvezőtlen telekformáció" dacára a tervező jól oldotta meg a feladatot. Zobel apróbb módosításokat vetett fel, általában kevesellte a „kényelmi helyiségek” számát, és javasolta, hogy azok udvarra nyíljanak. Leszögezte: az „irodahelyiségekre nézve, mint minimális méret $3 \mathrm{~m}$ (szélesség) volna megállapítandó", a traktus mélysége adott. Egyes lépcsők karjait szélesítendőnek látta. Számos terem természetes világításának elégtelenségét rótta föl: a díszlépcsőház „elöterme”, vagy, hogy az oldalhomlokzatok mögött a loggiás nagy terek javarészt indirekt fényt kapnak. Ugy vélte, hogy a Szentháromság tér felőli díszterek nincsenek „organikus összefüggésben” a főhomlokzat kialakításával. Egyfajta diszkrepanciát látott a legjelentősebb belsők és azok homlokzati megjelenítése között. Úgy ítélte meg, hogy ugyan a „választott csúcsíves, vagyis goth építési modor az egésznek (ti. a palotának) komoly monumentális jelleget kölcsönöz", azonban nyilván mindenekelőtt a Szentháromság téri reprezentatív szárny oppozícióba kerül a „gothikus remekmü"-vel, a Mátyás-templommal. Zobel azt javasolta, hogy váljon el a két épület stílusban egymástól; ajánlata szerint a német reneszánsz formáinak alkalmazásával. ${ }^{16}$ (3. kép)

A Fővárosi Közmunkák Tanácsa a 101/1901. számú Pénzügyminiszternek címzett válaszlevelében az ÉB f. év január 8-i leiratára tiszteletteljesen jelentette, hogy az „épület helyéül kiszemelt tömbben fekvő magán ingatlanok kisajátítására adott megbízásnak hazafias készséggel és buzgalommal" fognak eleget tenni (1901. I. 17.). ${ }^{17}$ Az ÉB hivatalból körözvényt adott ki 1901 márciusában a minisztériumi főosztályvezetőkhöz a módosított tervek megtekintése és véleményezése tárgyában. ${ }^{18}$
Egy levéltervezet szerint, amelyet Ney Béla minisztériumi tanácsosnak az Országház építési végrehajtó bizottsága előadójának küldtek; tájékoztatást kértek a Parlament épületén alkalmazott hazai kőanyagok minőségéről és szilárdságáról (1901. március 15.). Ney válasza szerint (március 23.) a szállítók garantálták azt, ill. Nagy Dezső műegyetemi tanár anyagkísérleti állomásán készültek hivatalos bizonylatok a bevizsgálásról, valamint a kért „feltét füzeteket" a vállalkozási szerződések általános és különös feltételeinek mintájaként megküldte. ${ }^{19}$

Fellner Sándor részére az „építési szerződés” 7. pontja alapján 1901. április 15-én tiszteletdíjának első részlete, 9000 korona „kiutalványoztatott”. Az aláírás nélküli szerződéstervezetet (1901. január 31.) ismerjük, ami Lukács László miniszter és Fellner Sándor budapesti müépítész között jött létre az épület létesítéséről szóló tc. alapján. Rendelkezett a tervek és részlettervek elkészítéséről, másoltatásukról, a művezetésről és az ütemezésről. A kiindulópont a 1900. december 31-én bemutatott vázlatok, áprilisra el kellett készülnie a teljes engedélyezési tervsorozatnak, egy hónapra rá pedig a költségvetésnek. Az első emeleti övpárkányt 1901. szeptember végére kellett elérni, a második emeletit pedig négy hónappal később, és 1902. július 31-re a belső munkákkal is késznek kell lenni. ${ }^{20}$

A Fővárosi Közmunkák Tanácsa 1901. május 25-én kelt levelében jelezte a Pénzügyminiszternek, hogy a magántulajdonú ingatlanok bontása a Majláth-féle ingatlan (2223 régi hrsz.) kivételével augusztusban megkezdhető. ${ }^{21}$ Az építkezés jelentős csúszással indult.

Fellner június 24-én levélben kérte honoráriumának második tizenkétezer koronás részének kifizetését, mert a tervezet és költségvetés elkészült és „,beterjesztetett”. Ezek után küldik be a Székesfőváros Tanácsához az engedélyezési eljárás céljára szolgáló 32 tervlapot és további négyet a régi kamarai épület átalakítására 1901. július 11-én. ${ }^{22} \mathrm{Az}$ építési engedélyt a főváros 52468/1901-III. (VIII. 6.) tanácsi számon adta ki. Kikötötték: az „alaprajzon kék színnel sraffírozott pillérek jó minőségü portlandcement habarccsal, a vörös színnel vonalazott pillérek pedig vízálló mészhabarccsal falazandók". A Szentháromság téri főhomlokzat III-IV. emeleti fő falának $60 \mathrm{~cm}$-ről $75 \mathrm{~cm}$-re történő vastagítását, erôsítését rendelték el. Pótlólag volt benyújtandó az összes vasszerkezetre, a vesztibülnél alkalmazandó vasrácstartóra, valamint a Breymann-féle (kompakt) mennyezet szerkezetre (Irattár) vonatkozó részlettervek és hordképességi számítások. A hétemeletes irattári tömböt annak ellenére engedélyezték, hogy meghaladta a beépíthető magasságot, de jellegében „raktárszerü”. Az épület „közjellegére” tekintettel 


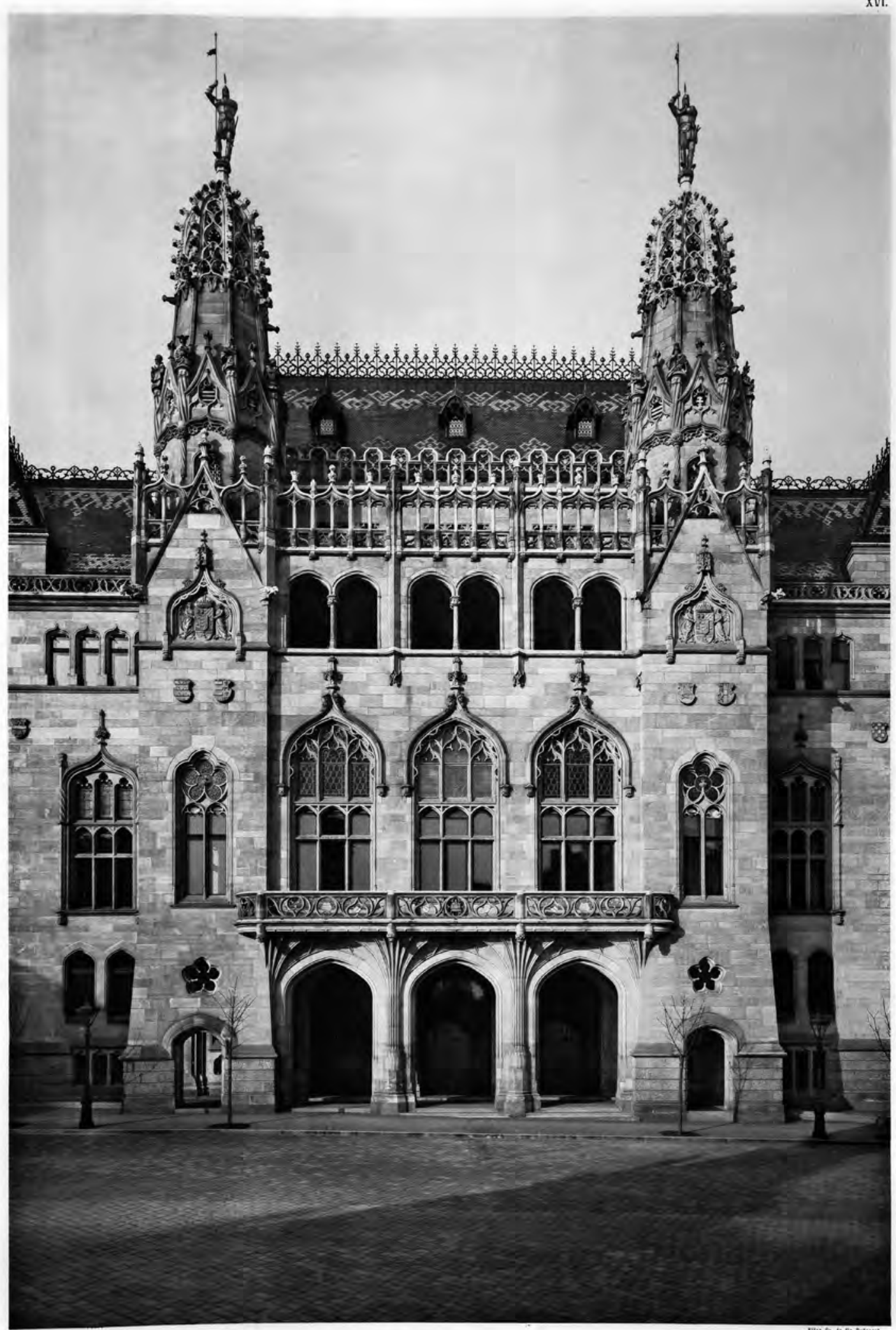

Fôhomlokzat részlete. - Vue partlelle de la facade princlpale. - Detail der Haupfíacade.

1. Föhomlokzat, középrizalit (Album, 1908. XVI. tábla) 


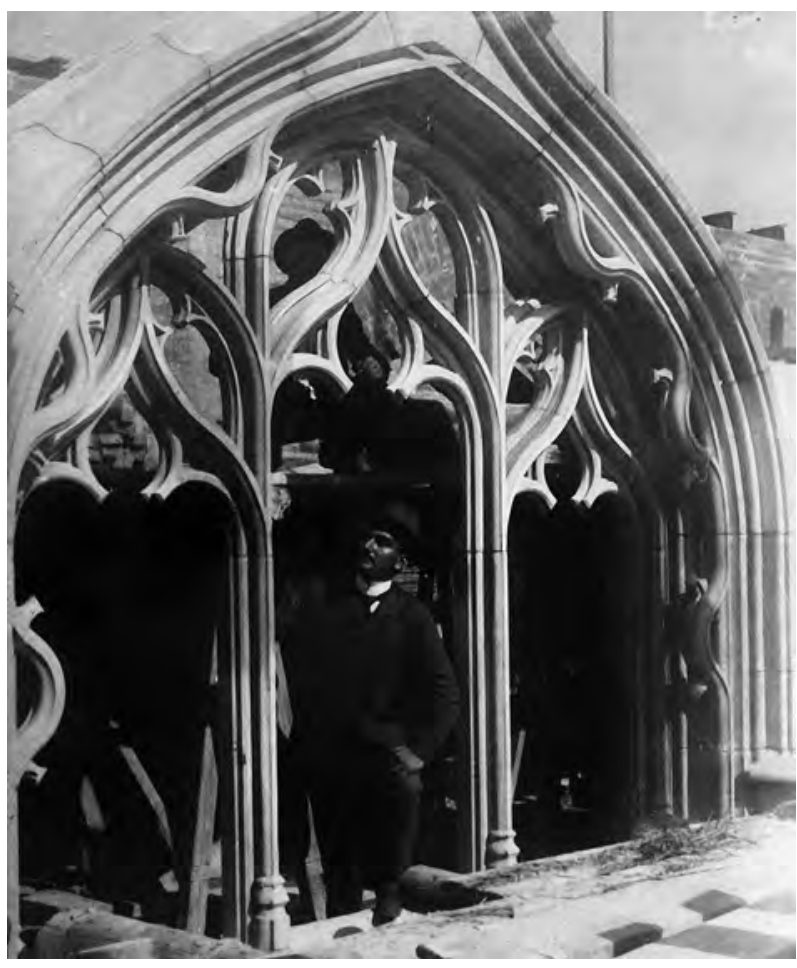

2. Fellner Sándor a középrizalit ablakában (1902 ösze) (Budapesti Történeti Múzeum, Kiscelli Múzeum, F.65.2823.4)

előírták az összes szabadon függő lépcső alátámasztását. A tervezett utcai „kiszökellékek” (a szabályozási vonalon túllépő rizalitok) is engedélyezettek, s az érvényben lévő „,terjedék-egyezmény” alapján a hivatal használati díjat nem állapított meg, az építési engedélyé 11892 koronára rúgott. ${ }^{23}$ (4. kép)
A Compact (kompakt) födém nemes Breymann de Schwertenberg Gusztáv okleveles mérnök (Budapest, Andrássy út 81.) és társa, a Magyar Monier Építési Vállalat szabadalma volt. A síkmennyezetes rendszer lényege abban állt, hogy „az eredeti Monier szerkezetben az egymás mellé sorakozó önálló mezők egy közösen hordó egésszé köttessenek össze, ezáltal a főtartók teherbírósága fokoztassék". A vasszerkezet egy rész cement, egy rész homok, öt rész tiszta salak betonanyaggal „csömöszöltetik ki”. A teherbíróság vonatkozásában egy 5,80 m szabadon fekvő $18 \mathrm{~cm}$ magas vastartók (átlag távolságuk egymástól $2 \mathrm{~m}$ ) között $8 \mathrm{~cm}$ vastag lemez négyszögméterenként 2800 kg-mal volt alakváltozás nélkül terhelhető. A lemez alátámasztó felülete $8 \mathrm{~cm}$, ebből $4 \mathrm{~cm}$ volt a falba eresztés, a másik fele az alatta lévő téglasor előre falazásából adódott össze. Állványon készült (zsaluzatban) a helyszínen, ami 8-15 nap múltával volt eltávolítható, simítása gipszes vakolattal történt. ${ }^{24}$

Az építkezés előkészületei időközben megindultak. Leféber Ágoston kútmester első számláját a „talajkémfúrások”-ról 1901. június 14-én nyújtotta be. ${ }^{25}$ Folyamatosan történt a szakipari munkákra az árlejtési hirdetmények közzététele és elbírálása. A legnagyobb volumenü szerződést először a föld-, kőmíves- és elhelyező majd a cserépfedési munkákra Majorossy Géza (lakik: V. Alkotmány u. 23.) vállalkozóval kötötték meg 1901. október 7-én, ill. 1902. június 14-én több mint $1100000 \mathrm{~K}$ értékben. ${ }^{26}$ A vasszerkezeteket, mindenekelőtt az A-szárny födémeihez és tetőzetéhez, a M. Kir. Államvasutak

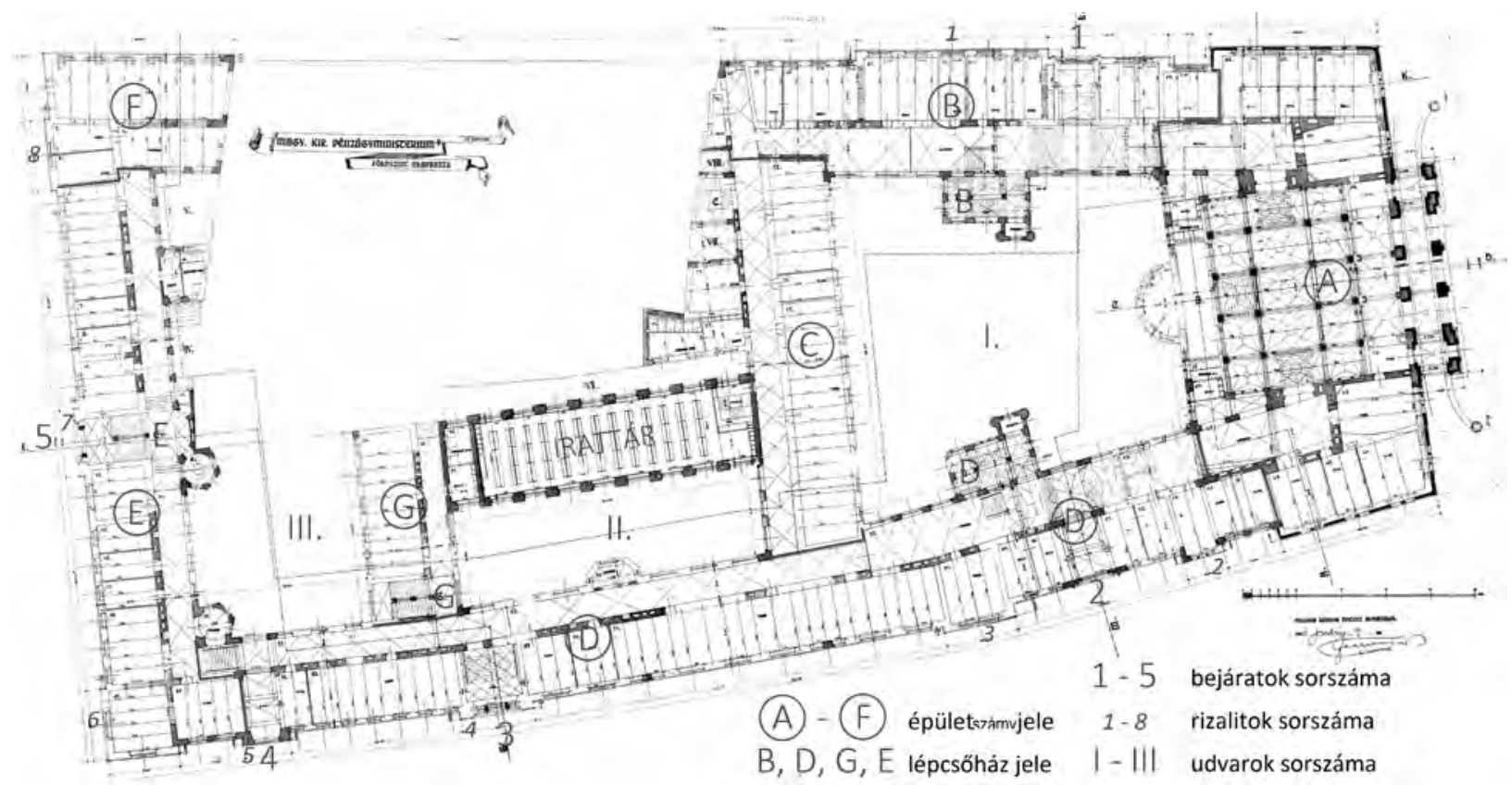

3. Földszinti alaprajz a kivitelezés irataiban használt jelölésekkel

(Budapest Föváros Levéltára, XV. 17. d. 329. 6590.540.d.fol. 14. [1901. VII. 9.] alapján) 
Gépgyára (X. ker. Kőbányai út, Diósgyőr) szállította árlejtésen kívül. ${ }^{27}$ A MÁVAG lakatosai végezték a szerelést, forrasztották a falkötő-vasakat, vágták méretre a nyíláskiváltások áthidalásait, a vas és bronz kőkötő-kapcsokat pedig ólommal öntötték be. ${ }^{28}$

A kőfaragó munkák kivitelére vonatkozó vállalati általános és részletes feltételek előírták a kőminták kötelező bemutatását. Tájékoztató ábrákat is mellékeltek, Fellner Sándor építész irodájából; idomkövek részben kottával, méretekkel ellátva. A szobrászi és bádogos munkák mintalapjain: kúszólevél, vízköpő, korlátbetét, keresztvirág, zárókő, bányászkalapács, zászlótartó vitéz etc. formákat vázoltak fel. Ney Ede és társa, aki elnyerte a kőfaragó munkára a megbízást, a legolcsóbb ajánlatot azzal érte el, hogy a várpalotai kőbányájukból származó kőre adták az ajánlatot, holott Kolozsvár vidéki kő volt elöírva, ami jobb minőségü, s mely már bizonyított, mint a Mátyás-templom tornya, az Országház, vagy az Igazságügyi Palota. ${ }^{29}$ Ney szerződésében meghatározták azon kőfaragványokat, melyeket az építésvezetőség kívánságára Magnesia-fluattal kellett impregnálnia. ${ }^{30}$

A telektömbön álló épületek bontása is megindult. A vállalkozó Grünwald Bernát 1901. október 24-én 25 munkanap hosszabbítást kért a szerződésbe foglalt október hó 1-hez képest, mert nem várt nehézségekbe ütközött: „az összes falak múlt századbeli alkotmány és kizárólag törmelékből áll". Az üregek tömedékelését is Grünwald végezte. ${ }^{31}$

Az Építési napló első bejegyzése (1901. október 5.) rögzítette a telek kitüzését, szintezését - a korabeli szóhasználatban: „lejtméretezés”, „felnivellálás" -, s az új épület földszintjének padlómagasságát a Szentháromság tér 5. számú ház falán (a minisztérium Elnöki épületén, melyet az építkezés előrehaladása során bontottak el, de addig az építésvezetőség irodájaként funkcionált f. hó 29-étől) +74,40 m-en jelölték ki. ${ }^{32}$ Graenzenstein Béla mint az Építési Bizottság elnöke az első kapavágást az F-szárny Fortuna utcai főfalának közepén tette meg 1901. október 10-én. ${ }^{33}$

A hivatalos alapkőletétel fél évvel később Isten áldásának kérése mellett 1902. április 15-én délben volt. A $80 \times 70 \times 51 \mathrm{~cm}$ méretü mészkő grundstein Ney Ede múhelyében készült, amelyet Lukács László és Graenzenstein Béla jelenlétében a Szentháromság téri és a Pázmány utcai főfal sarkán (összeszögelésében) raktak le jelképes kalapácsütésekkel kísérve, $245 \mathrm{~cm}$ mélységben az utcai járda alatt. Az alapkőben pénzek, napilapok és az épület madártávlati ábrázolása mellé elhelyezett $28 \mathrm{db}$ okmány - japán, merített és más papírokra - Hornyánszky Viktor kőnyomdájában készült (szövegük nem ismeretes). ${ }^{34}$

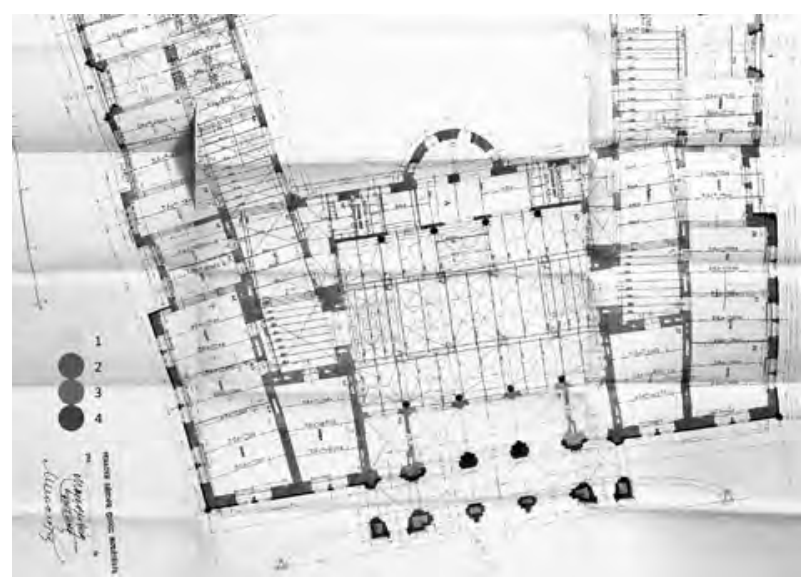

4. Módositott földszinti alaprajz részlete (Budapest Föváros Levéltára, XV. 17. d. 329. 6590. 541. d. fol. 39. Ép.eng. sz.: 143210/1903-III. [július 22.]) Jelmagyarázat: 1 (halványpiros) - közönséges téglafal, 2 (vörös) - erósített habarcsba rakott téglafal, 3 (lila) - portlandcement habarcsba rakott téglafal, 4 (kék) kóburkolat

Az Építési napló szerint az építési munkálatok a próbafúrások után az E- és F-, Fortuna közi szárnyakon földkiemeléssel kezdődtek meg. Reischl Ferenc építési ellenőr rögtön közölte Fellnerrel, ill. az őt képviselő Blastik Ferenc művezető építésszel, hogy minden reggel fél 8 órakor jelenlétükben helyszíni szemlét tart az építkezésen, valamint kedden, szerdán, csütörtökön és szombaton délután fél 4 órakor fogja ellenjegyezni az irodában a kiadásra került munkákat a határidők tartása és az elvárt minőség érdekében (1901. október 20.). A Naplóban is rögzítették a tervváltoztatásokat, lépésről lépésre az alapozási múveleteket; a sziklába „ejtendo””, megerősítésre (kibetonozásra, pilléres alátámasztásra) szoruló üregeket „kémlelő" furatok minimálisan 2 m-es mélységét a pinceszinttől számítva, keresve a hordképes ágyazatot. Elrendelték fagyveszély esetén a betonozás felfüggesztését, fütött munkaterületek kialakítását, az építési anyagokhoz a meleg víz használatát. Az irattári szárny kitüzésénél (1902. január 30.) kiderült már, hogy az Egyetemi Nyomda földszintes szárnyának részleges bontására és újraépítésére lesz szükség az északkeleti saroknál. ${ }^{35}$ Március 3-án az építésvezetőség „konstatálta”, hogy a kedvező időjárásra tekintettel a vállalkozó építőmester (Majorossy) „saját felelősségére a falazást és a lábazati kövek elhelyezését már a szabadban is megkezdette"! Április 3-án a felmenő falak (az irattári szárny kivételével) mindenütt elérték a Lánchídon elhelyezett „dunaszempont”-hoz, a számított $0 \mathrm{~m}$-hez viszonyított $+75,00 \mathrm{~m}-\mathrm{t}$, azaz túllépték a földszinti padlóvonal magasságát. Az irattár falazása április 26-án indult, május első napjaiban pedig a betonalapozást követően a föhomlokzat tornyainak alapfalazása. Május 16-ától az 
A-tractus „vestibule"-jében megkezdték a csarnok ívezeteit alátámasztó szegecselt vasoszlopok felállítását. A szekrénytartókat egy hónappal később szerelték fel azokra - mely munkákkal párhuzamosan helyezték el a B-szárny fedett erkélyének nagy vállköveit -, majd június 24-étől falazták a csarnok nagy íveit. Ez a munka július első dekádjáig eltartott. Ezt követte a díszterem és előtere íveinek falazása. Július 22-én érték el a lépcsőház apszisánál a falegyent. Dokumentálták az elhelyező munkáknál a rétegek számát, a főhomlokzati tornyokon 1902. július 16-án a XVIII. kősort és a koszorút helyezték el. ${ }^{36}$ Július 24-én láttak neki az erkélykosár elhelyezésének a főhomlokzaton egy hét alatt készültek el azzal. Augusztus 8-án Fellner utasította Majorossyt a kivitelezés tempója érdekében, hogy „kétnaponként egy-egy kőréteg helyeztessék el” a homlokzatokon, s utána falazás ennek arányában történjen. Azonban a főszárny „alapjainak egyenetlen" voltára tekintettel a kővel borított falak csak a harmadik emeleti fópárkányig húzassanak fel november 1-jéig (legyen idő az „összeülepedés$\left.\mathrm{re}^{\prime \prime}\right)$, majd ideiglenes tető alá kerüljön télre. Ugyanekkor elrendelték; a födémekben a párnafák tiszta homokba legyenek ágyazva, és e fölé kerülhet csak a salak. Melocco Pétert figyelmeztették, hogy a Concret födém törésig való terhelése még mindig nem valósult meg (augusztus 18.)! Valamint észrevételezték „,a vasbeton munkák megkezdése alkalmából”, hogy a helyszínen gyártott födémekben a sodronyháló nem ónozott, ezért a mennyezetfestésben vagy a kárpitozásban kárt okozó átütő rozsda felelőssége a vállalkozót terheli. Melocco a bejegyzésre reagálva leírta, hogy évek óta készíti ezt a födémet, s ilyen típusú probléma még nem adódott, horganyzott vagy galvanizált drótháló pedig csak külön rendelés esetén jár (augusztus 22.). Augusztus elejétől deponálták, halmozták fel az építési területen a tetófedő munkához a cserepeket. Az augusztus 21-ei bejegyzés szerint az A-szárnyban a XXVIII-XIX. kőrétegek mögött folytak a falazási munkák, vaskapcsok és falkötők elhelyezése a rétegek bekötésére. Az F-szárny II. pincéjében téglaboltozat készült vastartók között (szeptember 5.). A főhomlokzat Szentháromság tér felé eső főfalát a III. emeleten tovább vastagították $75 \mathrm{~cm}$-ról $90 \mathrm{~cm}$ re és az E-tractusban megkezdték a lépcsőtoronyban a csigalépcső elhelyezését (szeptember 5., 15.). Szeptemberben folyamatban volt a "villamvezeték” szerelése és a mázoló munkák a frissen elkészült tetőszakaszokon; párkány homlokdeszka, hófogók, bádog padlásablakok stb. ${ }^{37}$ Ebben a hónapban állították fel az elkészült tetőszakaszokon a kéményseprőjárda támaszait, folyt a Fortuna közi attika és a III. udvari kupola (csigalépcső-torony) bádogo- zása. Az épületen a kőművesmunkák dandárjának idején akár egy tucat pallér, közel másfélszáz kőmúves, 8-10 tanonc, félszáz körüli asszony, 50-60 állványozó, tucatnál is több lakatos és segédje, csaknem kétszáz napszámos és alkalmanként 50-nél is több iparos dolgozott, s az elöírás szerint legalább 100 lovas kocsi szállította az anyagot. Kossuth Lajos születésének 100. évfordulója, 1902. szeptember 19-én az iparosok számára munkaszüneti nap volt (ekkor tartották a falegyen ünnepélyt). Az építkezés tényleges állásáról a napló egyik fontos adata, hogy 1902. szeptember 29-én utasították Majorossyt a főlépcsőház feletti vasszerkezet ${ }^{38}$ azonnali felhordatására, a szárnyban ekkor az XLIX. kőréteg elhelyezése történt. Egyben felhívták Zsolnay (Vilmos sic) Miklós figyelmét arra, hogy a szobrászmunkák (fejezetek, tagozatok) késedelmes szállítása esetén, minthogy a héten Majorossy megkezdi a „leállásokat", az állványzat lebontását, az elhelyezést biztosító esetleges újbóli állványozás az „Ön kötelessége és költsége" lesz. ${ }^{39}$ Zsolnayval a pyrogranit, majolika és terrakotta szobrászmunkákra a szerződést 1902. július 9-én kötötték meg, 78870 korona értékben. Miként a szerződések többségénél rajzok hiányában a vállalt munkák részletezése korlátokba ütközik. Valamilyen ok folytán Zsolnay szerződésében szerepelt két tétel, amelyet külön díj, vagy ellenszolgáltatás nélkül ingyen elkészít és szállít a pécsi gyár: „a nagy csarnokba majolizálva nyolcz darab oszlopfejezet $0.80-0.60-0.72$ méretben és négy darab oszlopfejet 0.72-0.50-0.85 méretben", valamint a „III. bemenet melletti kis csarnokban (Országház utca) színes pyrogranitból három darab oszloptalapzatot 0.80-0.70-0.80 méretben és nyolcz darab féloszlop talapzatot ugyanezen minta szerint". ${ }^{40} \mathrm{Az}$ Építési napló utolsó bejegyzésében (október 22.): a D-szárnyban a tüzfalakat építették, az A-ban az LVI-LVII. kőréteget helyezték el, vakolási munkák is folyamatban voltak, s ablakkeretek kihúzása zajlott a Fortuna közben és az Országház utcában, a Pázmányban a bádog attika elhelyezését végezték. (5. kép)

Fellner az épületnél alkalmazásra kerülő vasszerkezetekről 1901. augusztus 23-án tájékoztatta Graenzenstein Bélát, ${ }^{41}$ 26-án pedig az új épület udvarán az Egyetemi Nyomdával kapcsolatos lépcsőáthelyezési munkálatokról. ${ }^{42}$ Langer Ignácz a kőszobrász munkák vállalkozója októberben 2080 K értékben elkészítette az épület gipszmintáját. Langer az alábbi sorok kíséretében tette meg ajánlatát a munkákra: ,,amennyiben müvészies tanulmányon alapuló kidolgozás igényeltetnék" a kivitelezés során, az ugyan költségemelő tényező, de „bátor vagyok felemlíteni, hogy a szobrászat terén, mint speciális középkori gothikus" vagyok ismert. ${ }^{43} \mathrm{Az}$ 


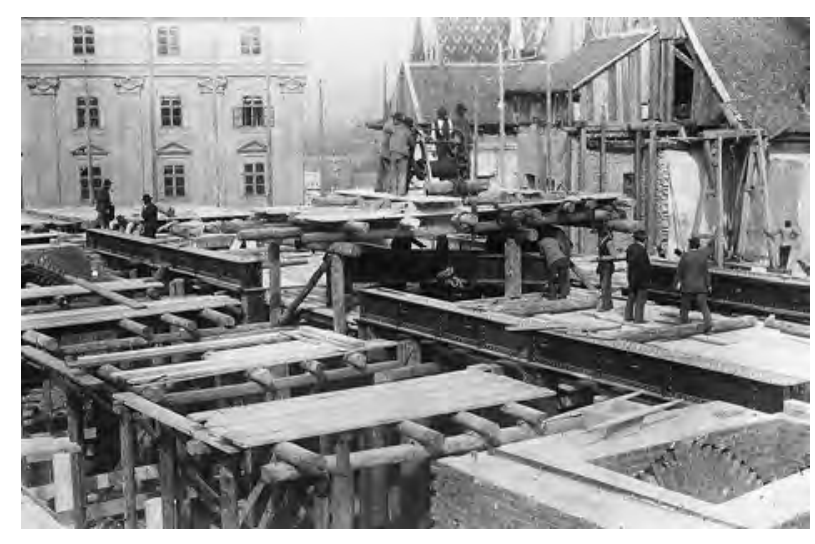

5. A szekrénytartók beemelése az elöcsarnok vasoszlopaira, háttérben az Elnöki épület maradványa (1902. június) (Budapesti Történeti Múzeum, Kiscelli Múzeum, F.65.28.23.5.)

épület ácsmunkáival már 1901 novemberében foglalkozott az Építő Bizottság, szerződést Neuschloss Károllyal kötöttek december 16-án. A munkák részét képezte a fedél(szék) építése mellett - amit a vállalkozó a telephelyén előkészítve tárol (1902. július 15-től) s az építésvezetőség rendelése alapján az adott rész felállítását három napon belül megkezdi - az ajtótokok kivitelezése, carboliummal való kezelése kártevők ellen. ${ }^{44}$

Jelentős változtatásról adott számot Fellner Sándor 1901. november 15-én Graenzenstein Bélának, az ÉB elnökének: a Kereskedelemügyi Minisztérium által felülvizsgált tervekhez képest az E-szárny Fortuna utca felé eső részén a földszinti folyosó szélessége 2,85-ről 2,50 m-re csökken, az utcai traktusé 5,70-ről 6,00 m-re szélesedik. Az Országház utca felé eső folyosó 2,85-ről 3,00 m-re, az utcai traktus szélessége 5,70-ről 6,00 m-re változik. A Zsolnay szerződésében említett 3 . számú bemenetnél a 25 . és 28. sz. folyosó kereszteződésében, a G-szárny (a II. számú udvart északról záró, haránt fekvésű „igtató") vonalában egy kis poligonális csarnok épül 3 falazott pillér helyett 3 körülfalazott vasoszloppal. Ugyanitt a földszinten a 46. és 54. számú helyiségek elhagyásával a csarnok az utca fő́faláig lesz kibővítve, az „elhagyott” tömör falak üvegfalakkal épülnek majd meg. Az A-tractusban a Szentháromság téri előcsarnokban a földszinten a tervezett gránitoszlopok helyett márvánnyal burkolt vasoszlopok "alkalmaztatnak”. A $16(4 \times 4)$ támasz közül a középső két sor, a ' $\mathrm{B}^{\prime}$ és ' $\mathrm{C}^{\prime}$ magja alakult át hengerelt szegecselt vastartóvá. ${ }^{45} \mathrm{Az}$ aláhajtó belvilága pedig $50 \mathrm{~cm}$-rel „,bővül”, magasodik. A földszinten a 71. számú „kamra” és a felette sorakozó helyiségek (I-III. emelet) kényelmi helyekké változnak. ${ }^{46}$ (6. kép)

Innovációs szempontból az irattár épülete, annak szerkezete a legérdekesebb. A szerződést 1902. június 14-én a Magyar Monier, Breymann G. és Társa céggel kötötték meg, aki a fentebb részletezett Breymann-féle kompakt födémrendszerrel pályázott. Fellner korábban a Debreceni Ipari és Kereskedelmi Bank bérházánál a folyosókon a Monierszerkezetet használta. ${ }^{47}$ Ajánlatot tett a Mátrai cég mellett (Mátrai-féle födém) Hegyi Ferenc vállalkozó is, aki a Feketeházy-féle szabadalom alapján épített volna, s egy Varsóban megépített cipőgyárra hivatkozott referenciaként. ${ }^{48}$ A Magyar Monier legerősebb versenytársa Melocco Péter (Beton és Vasbeton

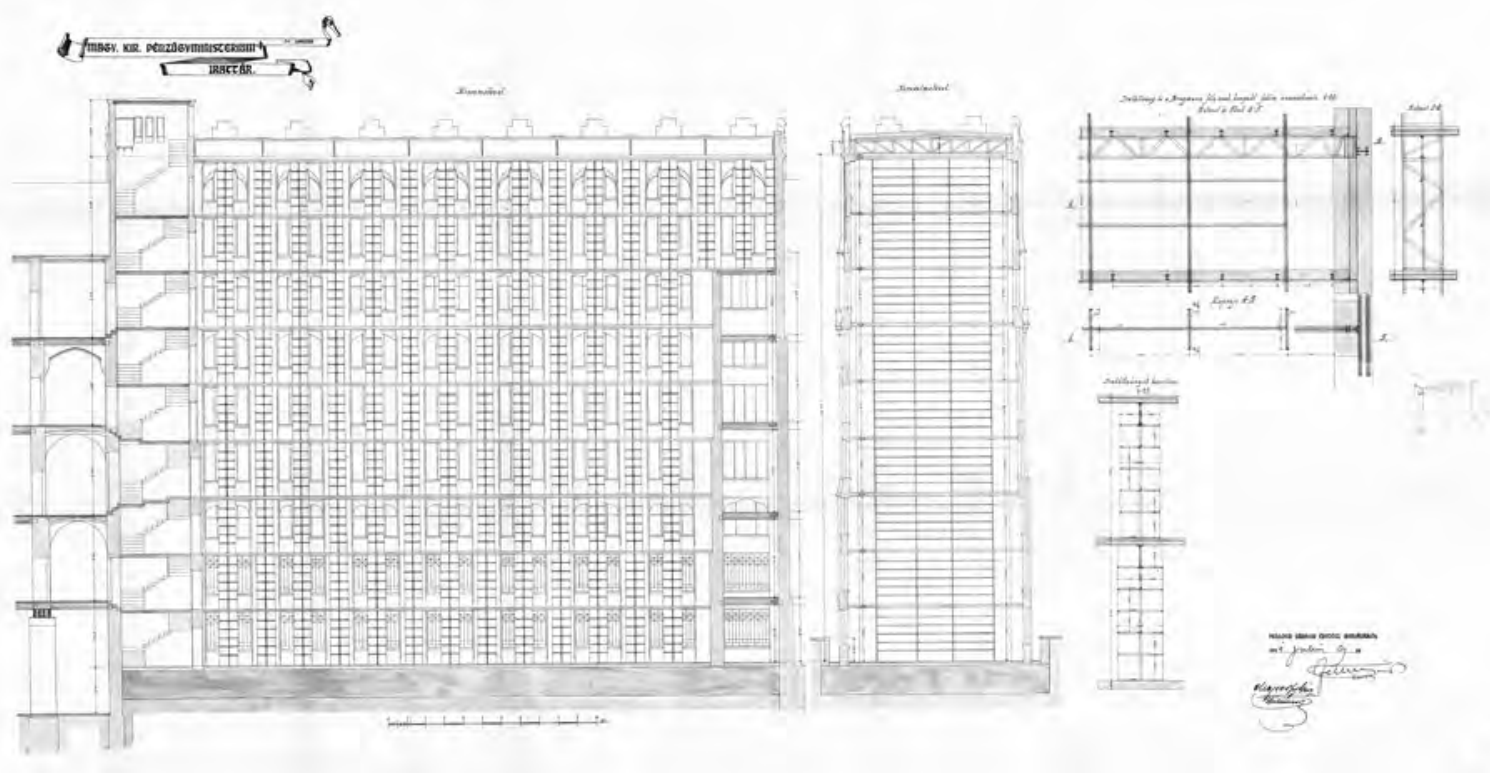

6. Irattár metszete (Budapest Fôváros Levéltára, XV. 17. d. 329. 6590. 540. d. fol. 22. [1901. VII. 4.]) 
Építési Vállalat) cége volt, aki a vasbetonmunkákra nyerte el a megbízást. Az ő szabadalmát képező felülbordás concret vasbeton födémei kerültek beépítésre az épület többi szárnyában. ${ }^{49}$ Melocco alternatív megoldást is javasolt, mert időközben megszerezte a Hennebique-rendszer építési jogát. Ajánlatát Zielinski Szilárd is aláírta, mint Hennebique műszaki képviselője a Magyar Korona országaiban, 1902. január 15-én. Melocco még a Fellner iroda iránytervét is módosította a cél érdekében. Azt javasolta elsősorban, hogy minden iratállvány-sor önálló betontömbön nyugodjon, így elkerülhető az esetleges eltérő mértékű süppedésből adódó törésrepedés az előterv szerinti egységes alaplemezen. Rácstartók helyett „szegecselt bádoggerendák”-at alkalmazott volna, miáltal a keresztirányban elhelyezett tartók mellőzhetőek, valamint a fémmel reakcióba lépő salakbeton kiváltását ajánlotta. ${ }^{50}$

Majorossy 1902. március 24-én kérte munkája után az első részletfizetés kiutalványozását keresetkimutatása alapján; az „,alapozási művelet” nagy része és nagy mennyiségü alagsor falazat elkészült. ${ }^{51}$

Fellner 1902. május 28-án újfent tervváltoztatásról számolt be az ÉB elnökének. A legfontosabb az volt, hogy a folyosókon, ahol a keresztboltozat vállpontja a fütőcsatornák irányába esik, azokon a pontokon az előirányzott téglaboltozatok helyett vastartók közötti téglaboltozat készül. ${ }^{52}$ Majd arról is tájékoztatta Graenzenstein Bélát, hogy Majorossy vállalkozóval egyeztetve éjjeli munkavégzés szükségességét állapították meg. ${ }^{53}$

Fellner jelentette az ÉB-nek, hogy júliusban elérték a főfalegyent, és intézkedett jutalmak kifizetéséről, a bokrétaünnepséget (Gleichenfest) szeptember 19-én tartották. ${ }^{54}$

A gőzkémény a „szomszéd jogokra” tekintettel került a (kazánházat magába foglaló C-szárny mögötti) II. udvarba, Majorossy kivitelezésében 1902. szeptember 16-ára készült el. A munkára a megbízást a vállalkozó, amit maga kezdeményezett, 1902. május 23-án nyugtázta. ${ }^{55}$ Kossalka János MÁV mérnök jelentést tett a palota födémei méretezése tárgyában (1902. október 26.). A számítások módja részben empirikus úton történt még. A vasbeton tömeges alkalmazásának kezdő évtizedében járunk ez idő tájt. A Melocco-födémeket augusztus 22-én terhelési próbának vetették alá. A tartók fesztávolságát $1 \mathrm{~m}$-től 2,15 m-ig vizsgálták, a beton keverési aránya a szabadalmi leírás szerint 1:3:4 volt; portlandcement, salak, kavics (a kivitelezés során 1:2:4re javították). A vizsgálatok igen kedvező eredményt hoztak. ${ }^{56}$ (7. kép)

A Boross Testvérek október elején benyújtották az ÉB-nak az elvégzett bádogosmunkáik után az 1. sz. kereseti kimutatást, Süss Hermann és Társa pedig ugyanekkor további villámhárító munkákra tette ezt meg. ${ }^{57}$ A Magyar Villamossági Részvénytársaság 1902. október 24-én tett ajánlatot az ÉB-nak, hogy a felvonók működtetését szolgáló áramot hektowattóránkénti 3 filléres, a világítási célú áramot 8 filléres egységárban szolgáltatnák. ${ }^{58}$ Az üvegesmunkák költségvetéséből a tokméretek adatai nyerhetők ki. Az ajánlati összeg 5\%-a volt a bánatpénz, melyre vonatkozólag letéti elismervényt is mellékeltek a vállalkozók, miként a többi kiviteli munkák esetében is. ${ }^{59}$ A fagördülő és csinvat (vászon) redőnyök szállítására Justus Sándor és fia cége nyert megbízást. Ajánlatához unikális építési adatokat is tartalmazó tételes kimutatást is mellékelt; a „nagyobb építkezésekhez szállított (!) gördülő faredőnyökről” 1892-1902. október 29. között. A listában Fellner is több tétellel szerepelt, mint építész, a kevésbé vagy alig ismertek: Keppich Imre és neje Schwarz Hermina (Budapest, Szobi utca, 1894), br. Hirsch Mór (Ógyalla, 1896), Schwarz (sic), (Simonmajor, ${ }^{60} 1898,40$ db-ot), Schwarz Lajos (Budapest, Nagy János [Benczúr] utca, 1898), gr. Széchenyi Béla (Felső-Segesd, 1902). ${ }^{61}$ Az A-szárny a téliesítés érdekében ideiglenes tető alá került 1902 novemberében a Neuschloss cég kivitelezésében. ${ }^{62} \mathrm{Az}$ építkezés előrehaladott állapotba jutott. Majorossy az év végén Graenzenstein Bélához fordult pótköltség igénnyel; hivatkozva arra, hogy a fedés jellege megváltozik, kisebb méretű lesz a cserép, hasonló, mint a Mátyás-templomé. Így ugyan tartósabb, viharállóbb lesz a héjalás, de négyzetméterenként három Koronával drágább a kivitelezés. A cserepeket a Zsolnay-gyár 1903. június 1-jén szállítja majd le. ${ }^{63}$ Ezzel összefüggésben a Boross Testvérek 1903. február 21-én kérelmezték, hogy a főhomlokzat díszei horganylemez helyett vörösrézből készüljenek a zománccserép tetőn. Illeszkedniük kell - érveltek - a toronycsúcsra kerülő „két hatalmas vörösréz lovag” figurájához is, melyek nem „chablon” szerint készülnek, hanem „müvészi kivitelü egyedi szobrok lesznek" ${ }^{64}$

Márciusban Fellner elrendelte az építésvezetőség nevében a főhomlokzaton már elhelyezett erkély mellvéd újból való megépítését, minthogy az „kifagyás folytán $3 \mathrm{~cm}$-rel kihajlott"! ! $\mathrm{A}$ Ney cég 1903 januárjában 9 db márvány ajtótokot, keretet szállított le, kettőt bunyitai (Erdély) márványból a főbejárathoz, teljesen csiszolva és fényezve, a többi bukovai kőből készült. ${ }^{66}$ Biebel János a márványmunkák vállalkozója jelentette Fellnernek március 4-én, hogy az 'E', 'G' szárnyak lépcsőházaiban a lépcsőfokok elhelyezésre kerültek, a 'B' és ' $\mathrm{D}$ 'ben még nem. Felhívta a figyelmet arra, hogy az oraviczabányai kő jobb minőségü, mint a kaprioriai „karsztkő”. (Graenzenstein oraviczai születésü 


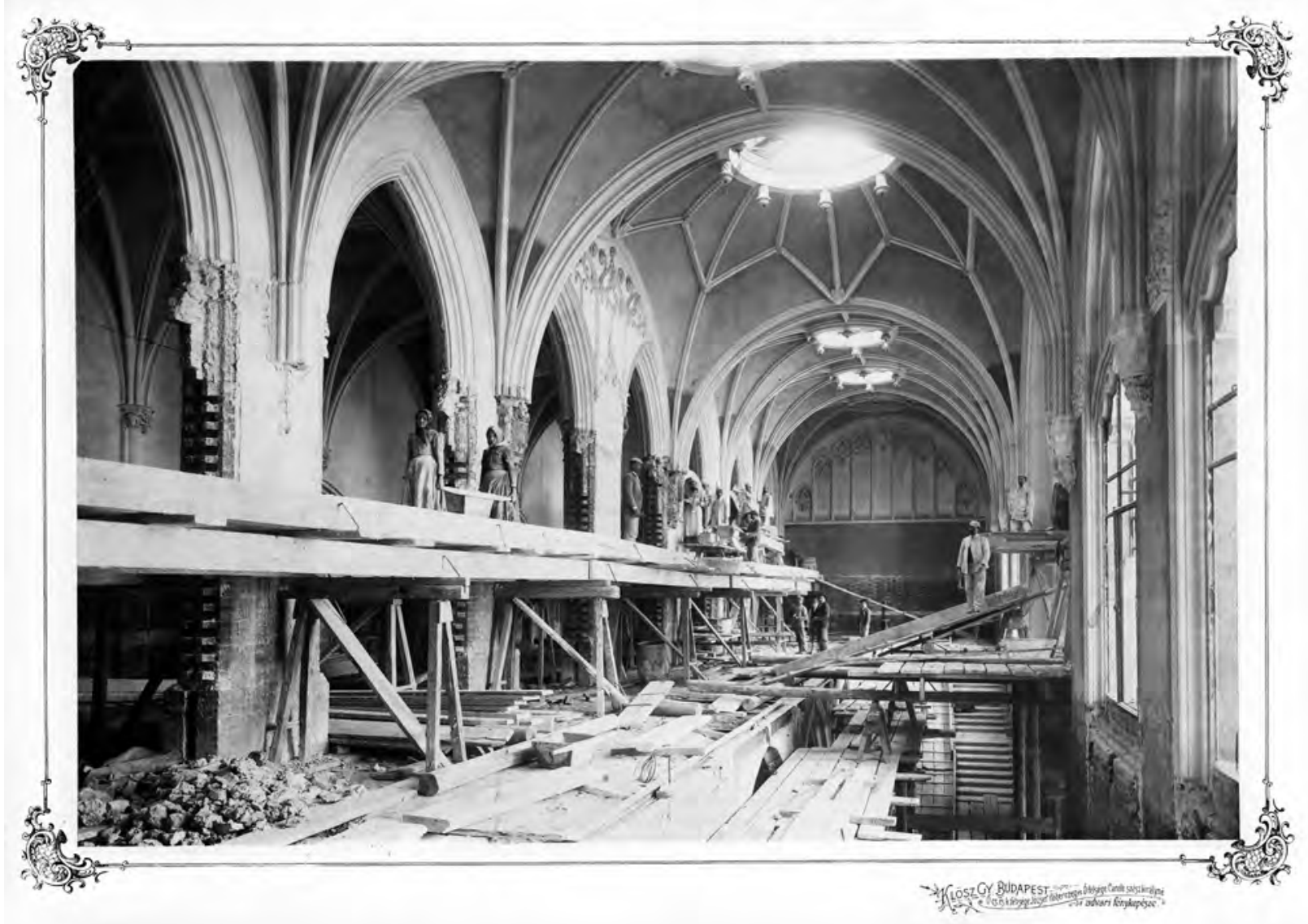

7. Az elöcsarnok fólépcsóháza épités közben. Klösz György felvétele (1903)

(Fortepan/Budapest Föváros Levéltára, XV. 19. d. 1.01.001)

volt, Biebel ott volt építész.) Kaprioriai sárga és rózsaszín márvány az anyaga az emeleti galéria könyöklőjének, a csarnoknak és előteremnek, a főlépcsőház és nagyterem burkolatának. ${ }^{67} \mathrm{~A}$ kaprioriai márványbányák kövét Seidner Miklós soborsini lakos szállította, aki „a lámpaoszlopok tekintetében” gipszmodellt kért Fellnertől. ${ }^{68}$ (8. kép)

Fellner 1903. május 18-án arról tájékoztatta Graenzenstein Bélát, hogy a könyvtárhoz vezető lépcsőt (A-szárny, III-IV. emelet) a toronyból a nagy elötérbe helyezné át a jobb közlekedés érdekében, valamint „Méltóságod szóbeli felhatalmazása alapján” Göncy Lajos szobrásztól 18 szobrot rendeltek meg, $16 \mathrm{db}$-ot a tornyokra, $2 \mathrm{db}$-ot azok ormaira (utóbbiak nyilván a rézlovagok) a Langer Ignácz kőszobrász szerződésében lefektetett egységárak alapján. Szépészeti szempontból szükségesnek látta Fellner az irattári víztorony lapos fedését, mely a liftszerkezetet is magába foglalta „,karcsú kupolával fedni". ${ }^{69}$

A „díszbejárat” aláhajtójában Gönczy Lajos akivel a vállalkozási szerződést 1903. június 17-én kötötték meg - munkája volt a 4 kő támfej: Lukács László miniszter, Graenzenstein Béla építési bizottsági elnök, Toepke Alfréd államtitkár és (toronyi)

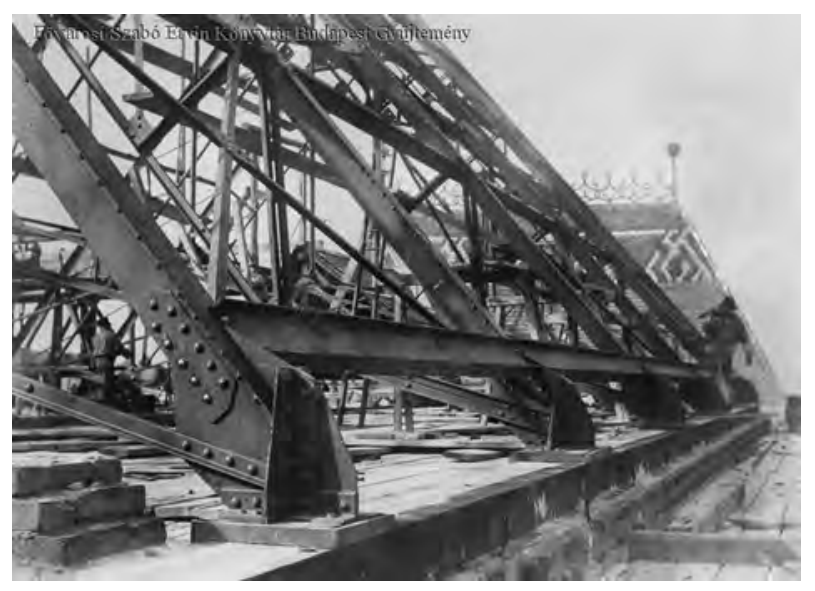

8. Az A-szárny, a könyvtár feletti tetô vasszerkezete, mögötte a miniszteri traktus tetözete (1903). (Fövárosi Szabó Ervin Könyotár, Budapest Gyüjtemény, 020912)

Fellner Sándor építész. ${ }^{70} \mathrm{Az}$ épületen felhasznált díszítőmotívumok összefüggésben voltak a „pénzügyi administráczióval”. Felhasználta Fellner, mint írta: az ország címerének babér- és cserfalombját, ezek mellett: „,a szöllöt, dohányt, gabonát, komlót, a kulcsot tartó kezet", a keresztbe rakott bányász- 


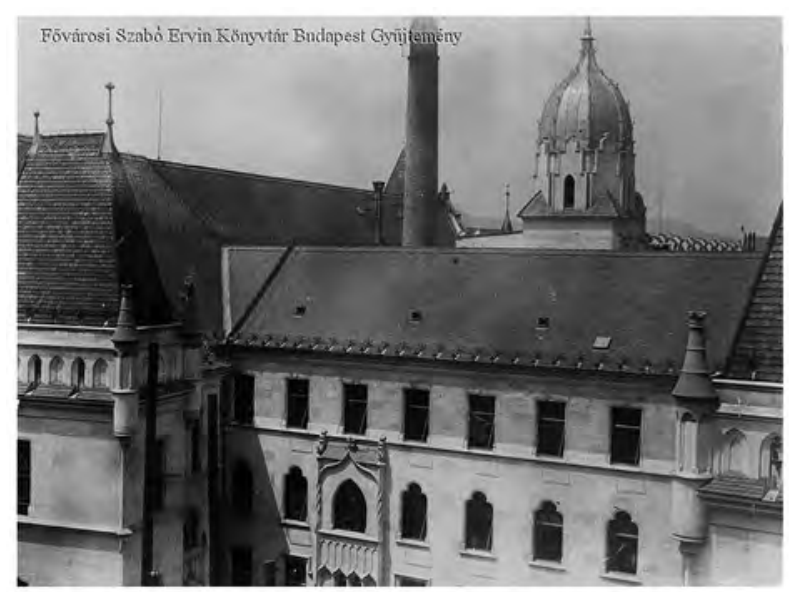

9. A C-keresztszárny díszudvari homlokzata a B és D lépcsóházak tetózetével, háttérben az Irattár tornya (1903) (Fövárosi Szabó Ervin Könyotár, Budapest Gyújjtemény, 020899)

kalapácsot, pergamenlapot. A toronycsúcs alatti vimperga közeit allegorikus félalakok gazdagították - a Tudomány, a Honvédelem, a Jog és Kereskedelem -, amelyek mindkét tornyon kétszer jelentek meg. ${ }^{71}$

Fellner február 2-án bemutatta Graenzensteinnek a toronysisak módosított mintáját, melyen megmagasította a kőívezetet, a hagymaívből kúpalakot formált. ${ }^{72} \mathrm{Ez}$ a „,festői” toronykupola megoldás viszszavezethető a bécsi Maria am Gestade tornyának kőrácsokkal áttört lefedéséhez. Miként a csúcsán felállított rézvitéz pár is (az Országházon állókkal egyetemben) Bécsre mutat, a Friedrich von Schmidt tervezte neogótikus városháza tornyán elhelyezett, Franz Gastell mintázta Rathausmann szoboralakra, amelyet Nehr Sándor készített el rézből (1882). ${ }^{73}$

A belső dísz- és rabitzmunkákra márciusban beadott ajánlati anyagból kiderül, hogy a csillagboltozatok, mint az I. emeleti 98. sz. miniszteri előteremben vagy az Országház utcai 2. sz. behajtóban, „vasívezetű feszítő kötővasakkal és veresréz hálóval készítendők, a bordák kihúzása gypszes mészhabarccsal történik, a sima mezők kivakolása pedig tisztára rostált fehér mészhabarccsal végzendő el". Érthető okokból kapta a megbízást Melocco Péter: a cég födémeire függesztették a termek és lépcsőházak rabitz-boltozatait. ${ }^{74}$ Melocco és a Magyar Kerámiai gyár rt. kőburkolati és kövező munkájának részét képezte a csömöszölt betonréteg készítése az alagsori helyiségek padlója alá, $1104 \mathrm{~m}^{2}$ egyszerü granitto terazzo (fekete, vörös vagy fehér márvány törmelékkel), $776 \mathrm{~m}^{2}$-nyi márványmozaik lap cementhabarcsba rakva a folyosókon. Finom márványmozaik lapból $300 \mathrm{~m}^{2}$ került a „kényelmi” helyiségekbe, a kiemelt jelentőségü folyosókon, lépcsőházakban és pihenőkön ugyanez bordürrel (szegéllyel) $358 \mathrm{~m}^{2}$-en, a loggiákban $113 \mathrm{~m}^{2}$ és rajz szerint (!) „gazdagon díszítve" a csarnokban és fölépcsőházakban $728 \mathrm{~m}^{2}$ felületen. ${ }^{75}$

Gregersen Guilbrand és Fiai a padozati és asztalosmunkákat nyerték el, a falak kárpitozását pedig Sieburger és Társa. A falak a szürke kárpitok feltétele előtt papírral voltak behúzandók a szerződés szerint. ${ }^{76} \mathrm{Az}$ irattár kivitelezésében, mint megállapították, „sietség szükséges” a befejezéshez (1903. június 19.). Az irategyüttes statikai számítást is tartalmaz a Breymann-féle födémről: „a kompakt lemezek vastartó kereteken fekszenek", a tartók távolsága átlag 2 m. A Magyar Monier, Breymann G. és társai levélben tájékoztatták Graenzenstein Bélát, hogy a főtartók távolságait megváltoztatták 1,15 m helyett 2,00 m-re ezért „,erősített vasbetétek alkalmazását rendelték el" ${ }^{77}$ Majorossy 1903. július 11-i kereseti kimutatásában szinte „teljesen kész” épületről számolt be. ${ }^{78}$ A Magyar Kir. Államvasutak Gépgyára a építkezés lakatosmunkáihoz más anyagok mellett 1500 kg ólomtömböt, 198 db bronz kőkapcsot, és egyéb vasanyagot szállított még a folyó év negyedik évnegyedében. ${ }^{79}$ (9. kép)

Más szakiparosok mellett 1903 augusztusában Gregersenék a padozati munkákról (hajópadló, táblás parketta) Neuschloss Károly ácsmunkákról, Zsolnayék pedig falburkolati munkákról nyújtottak be számlát. Meloccót kötbérrel fenyegették a burkolólapok késedelmes szállítása miatt. ${ }^{80} \mathrm{~A}$ vállalkozó nem ismerte el jogosságát, azzal érvelt, hogy a jó minőség érdekében az elkészült lapokat (márványmozaik, cement) raktározni, vagyis pihentetni szükséges. Éjjeli müszakban is gyártották a lapokat. ${ }^{81}$ A Székesfőváros Tanácsa 1903. augusztus 6-án arról értesítette Graenzenstein Bélát, hogy az épület készültségi fokának megfelelően elrendelte az új palota mentén az Országház és Pázmány utca kocsiútjának „zajtalan asphalt burkolását." ${ }^{82}$ Fellner magát a pénzügyminisztert tájékoztatta 1903. szeptember 5-én az alábbi költségvetésbeli változtatásról, mely összefüggésben állt a „,toronyalak” módosításával. Eredetileg a tornyok bordaköveinél (a Ney és Langer szerződésekben) 160 db krabba (kúszólevél) elkészítése volt tervbe véve. A változtatás eredményeként számuk 112-re csökkent. Másfelől puhamészkő helyett keménymészkőből történt a kivitelezés, ami többletköltséget eredményezett. Azonban „kiemelném - hívta fel Lukács László figyelmét Fellner -, hogy ezen anyag alkalmazásával az államkincstár érdekei a legmesszebbmenőleg biztosítva vannak, mert ezen anyag évszázadokig is daczol az idő viszontagságaival és nem kívánja meg úgy, mint a puha kő a javítást". ${ }^{83}$

Hein János aki az 1900. évi Párizsi Világkiállításon aranyérmet nyert kertterveivel, 1903. október 
20-án tett ajánlatot a palota udvarainak parkírozására: más növények mellett $158 \mathrm{~m}$ buxusszegély (3500 db), $8 \mathrm{~m}^{2}$ virágágy, $12 \mathrm{db}$ nyírfa, $1 \mathrm{db}$ Picea pungens 'Glauca' (ezüstfenyő) ültetésére. ${ }^{84}$

Az irattári költségelszámolásból kiderül, hogy a Magyar Monier-Breymann-födémeket a „legvégső minimumra" $14 \mathrm{~cm}$ vastagságra redukálták. A födém és a padozat (az irattári „,szegletvas"-gipsz állványzattal együtt) egy egység, s egymástól el nem választható betonlemez, ill. szerkezet. ${ }^{85}$

A Schlick-féle vasöntöde és gépgyár a könyvtárlépcsőt 1903 októberében szállította le és állította fel. ${ }^{86} \mathrm{~A}$ főhomlokzat állványzatának bontása előtt intézkedtek a díszkivilágítás kiépítéséről. ${ }^{87}$ Majorossy jelentette az építésvezetőségnek, hogy a díszlépcső elhelyezése csupán már a feladata, de a kőanyag még nincs leszállítva, holott az épület átadása 1904. május 1. lenne. Nehezményezte, hogy szerződés szerinti munkája az év nyarán csupán 20 ezer K értékű volt, ellenben közel 180 ezer K járandósága vár még utalványozásra. ${ }^{88}$

Fellner 1904. március 23-án kérte Graenzenstein Bélát tiszteletdíjának újabb részének kiutalására, mert az épület belső munkái legnagyobbrészt elkészültek. ${ }^{89}$

Hochmann József díszmúlakatos és Gregersen asztalos vállalkozók felszólaltak más iparosok mellett, hogy az ajánlati tervek alaposan átváltoztak kiviteli terv szinten, gazdagodtak, díszesebbek lettek: háromszárnyú ajtók helyett ötszárnyúak, hajlított, faragott vállpárkánnyal, típusok helyett egyedi darabokká alakultak át oldalankénti eltérő betétekkel. Az „építésvezetőség által megrendelt munkák csaknem kivétel nélkül oly pazar kidolgozásban rendeltettek meg..., hogy azoknak a költségvetés szerinti egységárakon való elkészítése nem csak szerény polgári hasznunkat emészti fel, hanem jelentékeny megkárosodásunkat is okozza" - írták Gregersenék. Ez többletköltséget eredményez, kérték a különbözetek megtérítését. (A kiviteli tervek nem lelhetők föl.) Hochmann 1905. március 9-én kelt, a tárgyban ismételt levelét egyenesen Lukács László miniszternek címezte. A némiképp bonyolult szövegezés általános tapasztalatot tükröz: a „palota csaknem valamennyi vasmunkái az építésvezető műépítész részéről oly masszív és díszes kivitelre és pedig a költségvetéshez adott rajzokból gazdagságra nézve teljesen eltérően lettek készíttetve, hogy alig van pár tétel, melynek költségvetési egységára önköltségemet fedezte". Felülfizetést kért, mint mások. Fellner általában vitatta ezek jogosságát. Azzal érvelt, hogy a vázlatokból a hozzáértő számára ki kellett derüljön, az elkészítendő munka valójában milyen. „Igaz ugyan - fedezte magát Fellner Graenzensteinnek írt levelében (1905. április 6.) -, hogy az 1:50-es méretben rajzolt vázlatok nem voltak természetes nagyságú részletek megrajzolásánál mindenben betarthatók, de sem az anyag, sem a föformák oly lényegesen nem változott, hogy azok új és költségvetés kívüli munkák számába mehettek volna... szerződés szerinti joga az építésvezetőségnek, hogy a szerződéshez csatolt vázlatokat szükségeshez képest módosítsa a nélkül, hogy a vállalkozó ebből kifolyólag több követeléseket támaszthatott volna. Tagadhatatlan, hogy kissé szokatlan stylus (!), a munkaárak tettemes (sic) drágulása és kivitel alatt számos strik (sic) bojkott stb. vállalkozók előzetes számítását sok esetben megdönthették..." Az „építtető minisztérium belátásától függ mennyire óhajt méltányossági szempontnak helyt adni...", hárította el az építész a kérdés megoldását. (Kiviteli, konszignációs tervek hiányában nehéz megítélni a változások mértékét. $)^{90}$

Zilzer Antal üvegfestészeti munkáinak 1. sz. kereseti kimutatását 1904. augusztus 1-jén nyújtotta be. A festőmüvész (Baross u. 41.) szintén felülfizetést kért, mert a tanácsterembe kettővel szemben hat festett ablak készült geometrikus mustrájú mozaikablak helyett. A nagy lépcsőház felülvilágítói is sokkal díszesebbek lettek, s itt még két nagy háromszárnyú ablakot és azok mérmüveit is mozaikkal kellett beüvegeznie. ${ }^{91}$ Ligeti Sándor üvegfestészete (Papnövelde u. 6.) 1904. december 18-án nyújtotta be számláját, a Nagyméltóságos Lukács Lászlót és Méltóságos Graenzenstein Bélát ábrázoló üvegfestményekért. Graenzenstein 1903. november 30-án utasította Fellnert, hogy a tervezett üvegezési költségek túllépése miatt a Szentháromság térre néző ablakokra javasolt „üvegfestészettől” teljes egészében tekintsen el. A Lukács Lászlót ábrázoló munkát bizonnyal a tisztikar finanszírozta és főnökük 10 éves miniszterségének ünnepén leplezték le a díszterem középtengelyében. ${ }^{92}$ Graenzenstein üvegportréja a tanácsterem Szentháromság térre néző ablakába került. Melocco Péter rabitz munkái tekintetében vis major helyzetre alapozta plusz költségeinek megtérítését; már a munkák kezdetekor a munkabeszüntetések miatt a 36-42 filléres órabér helyett 60 fillért volt kénytelen fizetni, hogy a határidőket tarthassa. ${ }^{93}$

A Szentháromság téri A-szárny 1903 végén került tető alá. Ekkor, október 11-én helyezte el a miniszter a rézszobrok egyikébe a befejezésről szóló okmányokat. A bádogos munkák általános és részletes feltételei, valamint költségvetése irategyüttesből ismerjük a „zászlótartó lovag” rajz szerinti megjelenésének részleteit: három méter magas volt, legnagyobb szélessége $70 \mathrm{~cm}$. Kellő erősségű vörösréz bádogból trébelték, ellensúlyokkal és vasmaggal is ellátták, s a lándzsában 


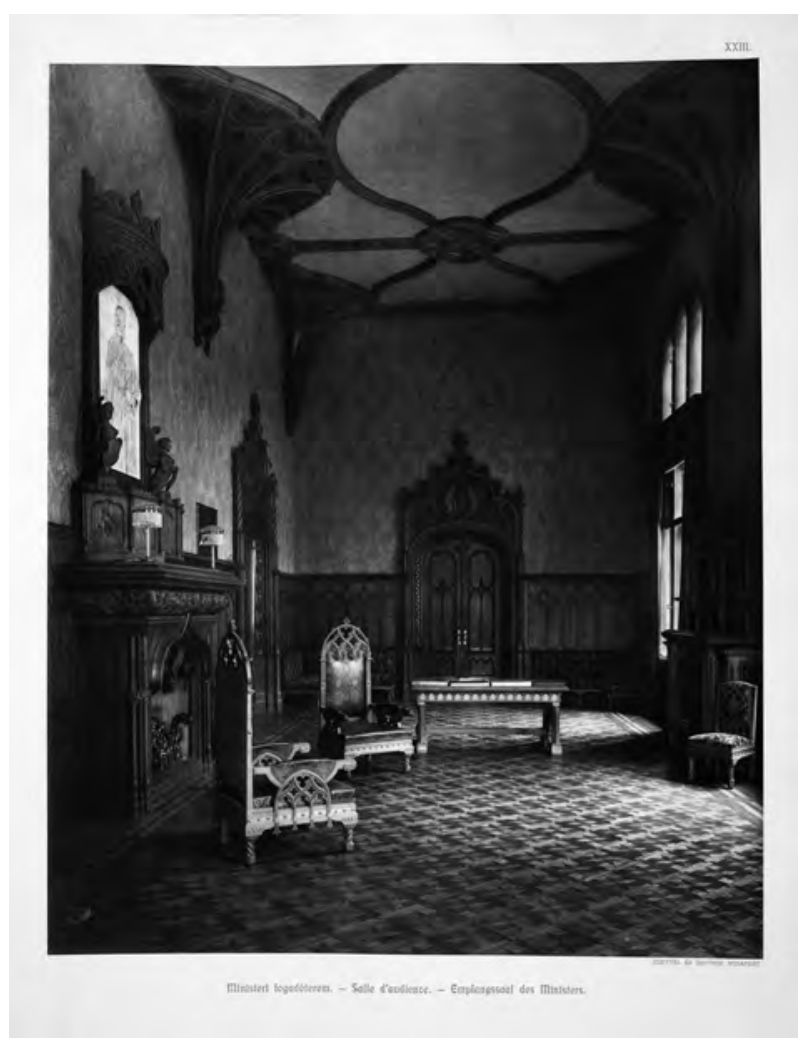

10. A miniszteri fogadóterem. (Album, 1908. XXIII. tábla)

a villámhárító huzalnak helyet kellett hagyni. ${ }^{94}$ Az év júliusában a hátsó frontokat már részben átadták rendeltetésének. A palota, melyben posta- és távirdahivatalt is kialakítottak, ${ }^{95} 1904$ végére készült el, ünnepélyes átadásról nem tudunk. ${ }^{96}$ A Haas Fülöp szállította, 136 méter hosszú és 230 cm széles sima, vörös, csomózott, a díszlépcsőre szánt szőnyeg számláját ugyan 1904. november 15-én keltezték, de a szállítási határidőt 1905. január 10-ében jelölték meg. Az épület A-szárnyának bebútorozása 1906-ig eltartott. Schmidt Miksa és más cégek mellett Thék Endre is szállított bútornemúket. ${ }^{97}$ Tiller Mór - Első és legnagyobb tiszti egyenruha-készítő intézet - már 1904. április 28-án kiállította számláját a Miniszter Úr Ő Excellenciája huszárja öltözetéről (kard nélkül) $1079 \mathrm{~K}$ értékben, melyből a díszmente 250, az atilla 230, de a kardbojt is 30 koronát tett ki. ${ }^{98}$ (10. kép)

Graenzentstein 1905 áprilisában kérte az I. kerületi elöljáróságtól a végső használatbavételi engedélyt, mert a Szentháromság térre néző dísztermek is elkészültek, valamint a telkek egyesítését. ${ }^{99}$ Gönczy Lajos Ố Felségét a Királyt ábrázoló márványba faragott domborműves térdképének 4000 koronás tiszteletdíja utolsó részét 1905. december 23-án kapta meg. A múvet a miniszteri fogadóterem kandallója felett $6 \mathrm{~m}$ magas fa díszkeretelésbe helyezték. Ez „audienciás termet harmadfél méter magasságig tölgy és kőrisfa talapzat" díszítette, a mennyezet dekoratív legyező boltozatot kapott. ${ }^{100}$ A „nagy fogadóterem” (a díszterem) volt a leggazdagabban kiképzett; „,könnyű övezete (ívezete) sárga márványból és majolizált zöldesszürke talapzatból" emelkedett ki, az ablakokat üvegfestmények, a hosszanti falakat két kőkandalló díszítette. A gerendás mennyezetű miniszteri váróterem falait négy méter magas tölgyfa burkolat födte, ebbe illesztették bele a „,camerae praeses-ek [kamarai elnökök] történeti értékü" arcképeit. A burkolat felett a fal szürke bársonnyal volt bevonva. ${ }^{101}$ Néhány évvel korábban Hauszmann Alajos az Országház téren álló Kúria épületében Telepy Károllyal restaurálta és „egyenlő méretre hozva három tanácsteremben képszék gyanánt, chronologikus rendben stukko rámázattal körülvéve" sorakoztatta fel az országbírók és a személynökök arcképeit, amelyek korábban a Kúria Ferenciek terén állt régi épületét díszítették. ${ }^{102}$

Jegyzőkönyvbe foglalták 1906. június 19-én, hogy a II. emeleti 64 . számú helyiségben mintegy két $\mathrm{m}^{2}$ felületen az egy $\mathrm{cm}$ vastag mennyezeti vakolat levált, de így legalább megállapítható volt, hogy a concret födém hibátlan. ${ }^{103} \mathrm{Az}$ irattár tetőzetén egy 1906. szeptemberi számla szerint a MÁVAG utólagos tömítési munkákat végzett, melyhez hegyikrétát, kopaline-t, ólomfehéret és ólompírt használtak. ${ }^{104}$ Fellner 1907. október 7-én jelentette az Építő Bizottságnak, hogy az épület „,̈̈sszes munkái és elszámolásai befejezést nyertek". Fellner levelében újfent kiemelte hét éven át volt müvezetője, Blastik József építész érdemeit. ${ }^{105}$ Fellner hangsúlyozta, hogy az építkezés körül felmerült számos "complikált" kérdés „szokatlan gyorsasággal" nyert elintézést, ami biztosította a munkák aránylag rövid idő alatti befejezését, s ez a Kincstár számára lakbérekben tetemes megtakarításokat eredményezett. ${ }^{106}$ A Majorossy Géza vállalkozó teljesítette alapozási munkálatok utó-felülvizsgálatát 1907. október 29-én tartották meg. ${ }^{107}$ Ekkor az épület főhomlokzatát az Országház és Pázmány utca sarkán felállított egy-egy ívlámpa világította meg. ${ }^{108}$ Fellner utolsó dokumentált tevékenysége az épületen, hogy 1918 októberében Popovics Sándor pénzügyminiszter részére gépkocsiszínt tervezett a díszudvarba, ami az azóta elfalazott ' $\mathrm{D}$ ' bejáraton át lett volna megközelíthetö. ${ }^{109}$

A Fellner tervezte épület megítélése már elkészültekor is ambivalens volt, mivel léptéke és túldíszítettsége miatt nem illeszkedett megfelelően a környezetéhez. A nyugtalan, kiegyensúlyozatlan részletképzésű főhomlokzat a Szentháromság tér domináns elemeként gyengítette a Mátyástemplom megjelenésének hatásosságát. A háborús 
pusztítást követő újjáépítés során az épületet egy emeletsorral csökkentették, így a környező beépítés arányaihoz közelítették a Pénzügyminisztérium magasságát. A Szentháromság téri szárnyat Rados Jenő formálta át téglány tömegü „palotává”. A föhomlokzat két-két szélső tengelyét megtartotta, a rizalitot elbontotta, annak három nagy ablakát az új homlokzatsíkba visszaépítve hozta létre a mai állapot. ${ }^{110}$ A Magyar Nemzet cikkírója megelégedettséggel fogadta az épület átalakítását: „Levetette cifra gőgjét, hivalkodását, s erősebb lett tőle... cifrálkodásaitól szabadultan" vált igazán monumentálissá. ${ }^{111}$

\section{A Fellner-féle épület leírása}

A szimmetrikus elrendezésü, változatos tömegformát mutató Szentháromság téri szárny, az épület egészétől eltérően kétemeletes, plusz tetőemeletes volt. Fő vonásában kilenctengelyes. A főhomlokzat középső öt tengelye rizalitszerüen előlépett, az 1. és 5. a toronypár alépítményét képezte. A behajtó nyomott csúcsíves három nyílása felett emelkedett a piano nobile, melynek erkélyét legyezőboltozat imitáció támasztotta alá. Három nagyméretű mérmüves ablakát szamárhátíves vimperga keretezte, a keresztvirágok talpánál portrépárok faragványaival. Előttük az erkély szintén mérmüves korlátja futott végig. Fölötte ikerablakokkal megnyitott nyitott loggia húzódott, melyet vimperga sor koronázott. A toronyépítmény e szintjén, kétoldalt a szamárhátíves fülkében az ún. angyalos magyar középcímert helyezték el. A toronytest efölött nyolcszögbe váltott. A sisak áttört csúcsán rézből trébelt dárdás harcos figurája állt. A torony alépítménye átjáróval volt megnyitva, fölötte rózsaablak nyílt, amelynek formáját az egy szinttel feljebb lévő háromkaréjos záródású ablak mérműve ismételte meg. A tornyok mögött a rizalit meredek haránt nyeregteteje magasodott, kétoldalt kőráccsal díszített oromfallal zárva. A szélső két tengely a középrizalit szamárhátíves ablakának egyszerűbb változatát képviselte az első emeletben. A főpárkány áttört attikája ezen a szakaszon szintén leegyszerüsödött és befordult az oldalhomlokzatokra. A kőlappal burkolt frontokat történelmi címerpajzsok (pl. Árpád-ház, Anjou, Hunyadi) is díszítették. A kocsialáhajtó indításánál kétoldalt gazdagon tagozott zászlótartó pár magasodott. A két háromtengelyes oldalhomlokzat tagolása megegyezett a fóhomlokzat szélső szakaszaival. A középső ablakot erkéllyel alakították ki. A meredek kontyolt nyeregtető a főhomlokzatra merőleges volt.

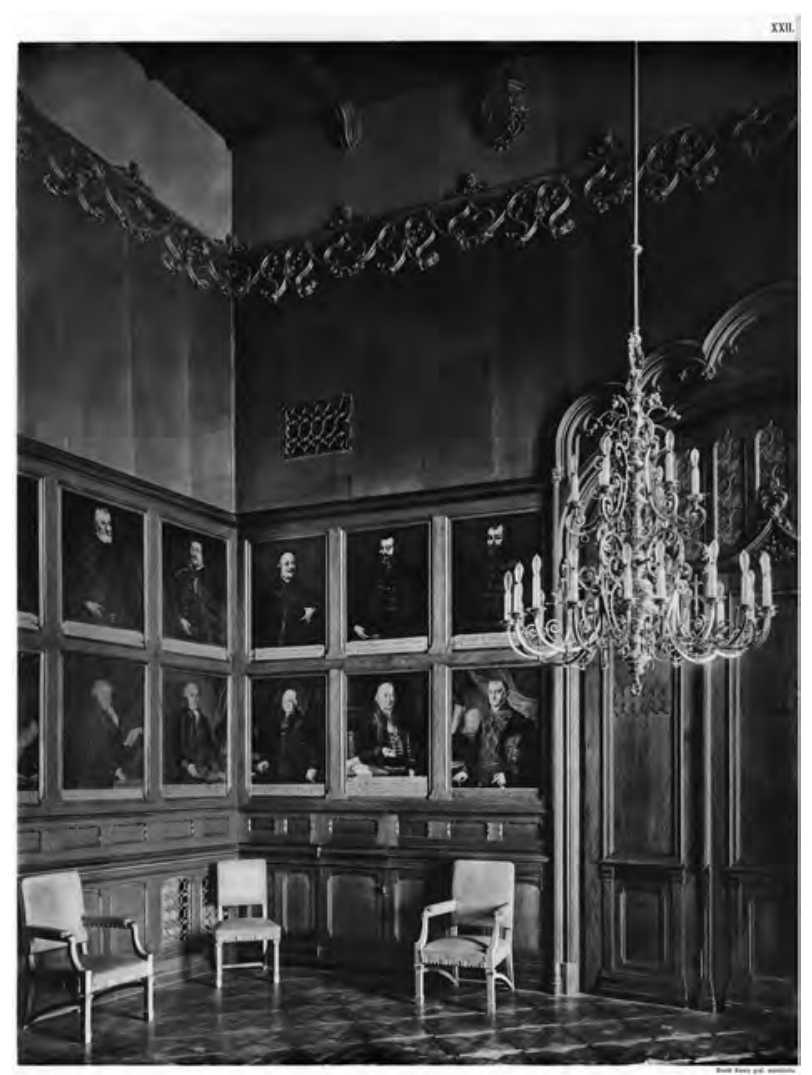

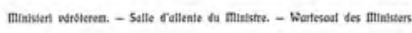

11. A miniszteri váróterem a Magyar Kamara elnökeinek galériájával. (Album, 1908. XXII. tábla)

Fellner leírása szerint a reprezentatív belső terek az alábbiak szerint épültek ki. Az árkádos aláhajtóból jutunk a háromszakaszos keresztboltozattal fedett előcsarnokba (szélfogó). A főbejárat három kovácsoltvas kapuzata Farkas Gyula és társai keze munkáját dicsérte. ${ }^{112}$ Két szélét a portáspáholy határolta. Az előcsarnokból jutunk a nagycsarnokba. A kettő együtt négyzet alaprajzú térrész. A csarnok csillagboltozatát tizenhat oszlop támasztja alá. Középtengelyben indul a főlépcső 5 méter széles karral. A pihenője sokszöggel záródik, ahonnan jobb- és balkézre egy-egy 4 méter széles kar visz az emeletre. Az apszis jellegü pihenő ablakmélyedéseit pirogránit padok töltik ki. Felettük figurális díszítésú ívezet köt ablaktól-ablakig. Az apszis nyílását márvány lámpatartó pár szegélyezte, melyeknek csak a talapzata maradt meg. A lépcsőkarok megvilágítását négy függőmérmúves ablak, az apszis ablakai és a hét szakaszos csillagboltozat üveg felülvilágítói ( $5 \mathrm{db}$ ) biztosítják. A lépcsőház terét az első emeleten üvegezett árkádsor választotta el a díszterem előterétől, ahonnan bejárás nyílt a két szintet átfogó hálóboltozatos díszterembe. Ennek terét aszimmetrikusan egyharmad : kétharmad arányban pillérsor osztotta két hajóra. A Szentháromság tér- 


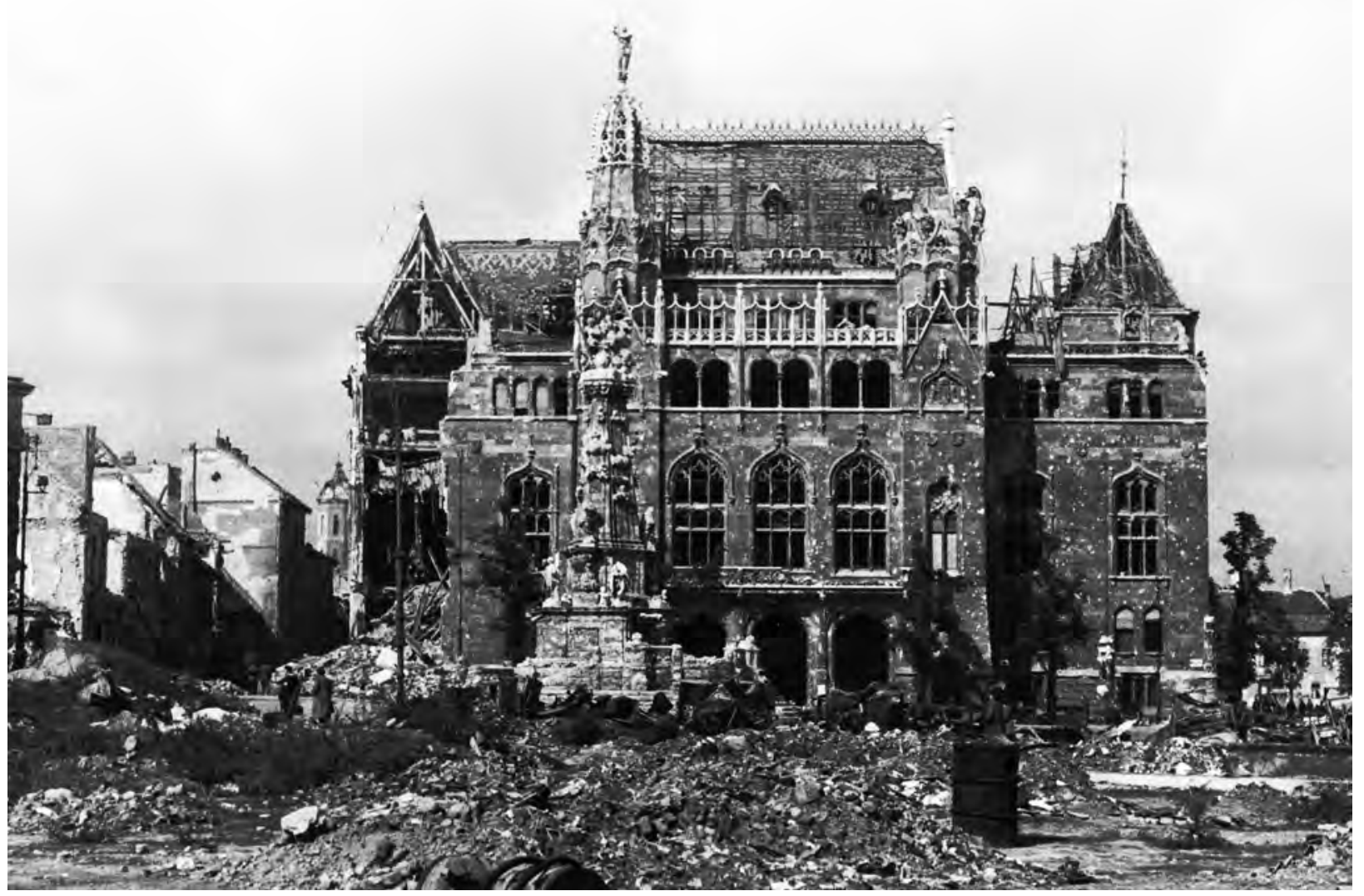

12. A Szentháromság téri föhomlokzat az ostrom után, életveszély-elháritás közben (1945)

(Budapesti Történeti Múzeum, Kiscelli Múzeum, 26.783)

re tekintő erkély mögötti térrész volt a keskenyebb. (11. kép)

A díszterem keleti végén lehetett belépni a Királyi Kamara elnökeinek portréit ${ }^{113}$ felsorakoztató miniszteri váróterembe, onnan lehetett továbbjutni a miniszteri fogadóterembe, amelynek bordákkal tagolt síkmennyezete tölcséres alátámasztású volt. E termek úgyszintén két emeletet átfogó belmagasságúak voltak. A fogadóterem pandanja volt az államtitkári szárnyban a tanácsterem, amelynek három ívrészből összeálló teknőboltozata ácsszerkezetet imitált. A hosszoldal két ajtajának szupraportjában Kossuth Lajost és Lónyay Menyhértet - a Batthyány-, ill. az Andrássy-kormány pénzügyminiszterét - mintázták meg. A díszterem feletti két szinten a térképtár, a könyvtár, és az olvasó kapott helyet.

A Hess András téri B-szárny tömegében hozzávetőleg szimmetrikus, középrizalittal képzett volt. Magasföldszintes, háromemeletes, kváderezett, vakolt (valószínúleg román cement) homlokzatú; lábazatát a Szentháromság téri oldalhoz hasonlóan alakították ki. A Szentháromság téri szárnyhoz nyaktaggal kapcsolódott, amelynek fő motívuma a miniszteri fogadószoba vimpergás loggiája volt.
A nyaktag és a rizalit közötti szakasz kéttengelyes. A földszinten jobb kézre nyílik a kettős szamárhátívvel keretelt kapuzat. Az ívek között a középcímer került elhelyezésre. Fölötte felirat: „Magy. Kir. Pénzügy Ministerium". ${ }^{114}$ A fogadószoba és a miniszteri dolgozó ablakai hármas osztásúak voltak, mérművekkel díszítve. Fölötte a hármas tengelyosztást megtartva nyíltak egyszerübb kivitelű ablakok. A legfelső szinten keskeny állótéglány alakú ablaksor futott. A középrizalit öttengelyes, szintenként eltérő ablakformákkal. Az alagsorban négyzethez közelítő, vasráccsal szerelt, fölötte háromkaréjos, az első emeleten könyöklőpárkány fölött páros függönyíves, a harmadik emeleten jelentős méretü gazdagon tagozott csúcsíves ablakok készültek. E fölött az osztópárkányon Tudor-íves ablaksor futott, minden harmadik vak volt. A főpárkány fölött vakmérmüvek között oromzatos tetőablakok álltak. A rizalitot oromfalak között kiemelt nyeregtető zárta le, a gerincét díszítő rács hangsúlyozta. A rizalittól jobb kézre eső szakasz öttengelyes.

Az oldalsó szárnyak díszudvari lépcsőházait a miniszter, illetve a két államtitkár használta, ezért kellően reprezentatív formában épültek meg. 


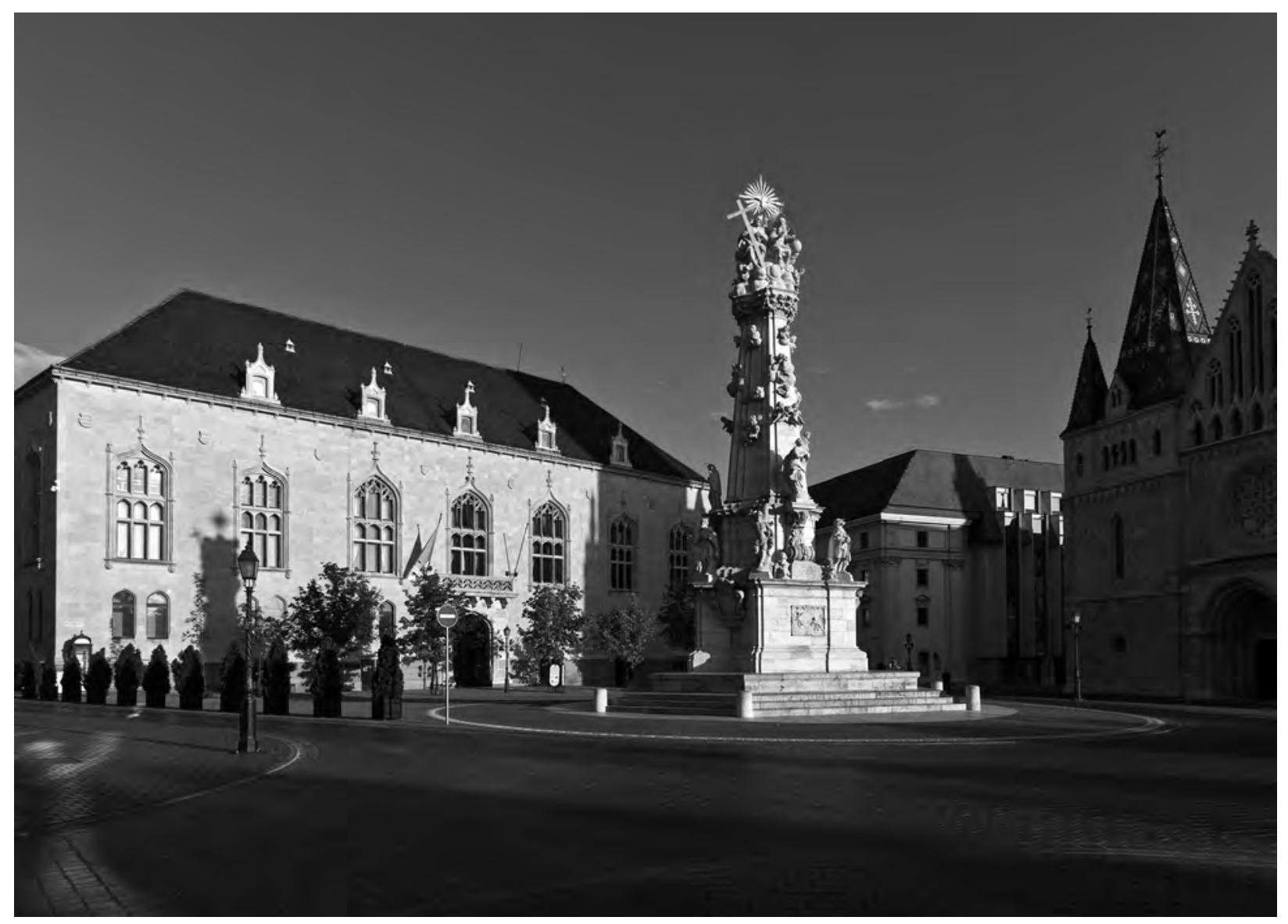

13. A Szentháromság téri fóhomlokzat (Nagy Krisztina felvétele, 2015. november)

A Hess András téri kapualjból $(+0,00)$ a belső traktusban, a folyosó vonalában déli és északi irányban tíz, illetve tizenegy fokú, teljes traktusszélességü lépcső vezetett fel egy-egy pihenőre. Az északra induló lépcső tágas pihenőre érkezett $(+1,65)$, ahonnan nyugat felé a lépcsőházba lehetett jutni. Három lépcsőkar vitt fel a főemeletre: hat lépcsőfok vezetett a lift előtti pihenőhöz (a lift innen közlekedett az emeletekre), a további két lépcsőkar tizenhattizenhat fokkal vezetett fel a föemeletre. Az 1,65 m-es pihenőszintről észak felé egy ajtón keresztül a fél folyosószélességü, tízfokú lépcsőn érkeztek a tisztviselők az alárendeltebb szerepü földszintre $(+3,45)$. Ennek a keskenyebb lépcsőnek déli megfelelője közvetlenül csatlakozott a kapualjból felvezető lépcsőhöz. Az alagsor felé a földszinti folyosóról közvetlenül a félfolyosónyi lépcső érkezése mellett nyílt egy ajtó, és két lépcsőfokkal lejjebb, a lépcsőház félemeleti pihenője alatti pihenőbool a lift gépházához vezetett le egy lépcsőkar. ${ }^{115}$ A B-szárny I. emeletén található miniszteri szobasor a vendégek számára a Szentháromság téri szárnyból volt megközelíthető, az ott található miniszteri fogadóteremből nyílt a miniszteri fogadószoba, amelyet a miniszter dolgozószobája követett.
Az Országház utcai D-szárny homlokzata az épület leghosszabb frontja. Vonalvezetése tört, tengelykiosztása hozzávetőleg szimmetrikus. A Szentháromság téri szárnyhoz nyaktaggal kapcsolódott, melynek első emeletét mérműves kőkorlátú erkély díszítette, melyet középkonzolon nyugvó szegmensív pár támasztott alá. Az erélyre két, szamárhátíves ablakajtó nyílt. A második emelet ívesen záródó négy elemből álló ablaksorában a középső ablakpár csavart oszloppal szegélyezve kissé előre lépett homorú vonalvezetésű oromzattal lezárva, csúcsán sas madárral (turul). Az oromzat mögött a hátralépő harmadik emelet előtt kis terasz húzódott. A homlokzat folytatása toronyszerú építménynyel indult és záródott a Fortuna közi szárny csuklópontjában. Lemetszett sarkait a legfelső szinten mérmúves szerkezettel alátámasztott féloszlop-pár szegélyezte, melyre bikafejes esővető került (2-2). Miként az esővetők többsége, ezek is csupán díszítő funkciót töltöttek be, s bizonnyal nem kemény kőből faragottak voltak, hanem a Zsolnay-gyárból származtak. ${ }^{116}$ A rizalitok között, az emeleti falazatok téglabetétesek voltak. A homlokzatot három rizalit és két zárt erkély tagolta. A lábazati anyag kő, a földszint és a rizalitok vakolatba karcolt 
kváderes (román cement?) kialakításúak voltak. ${ }^{117}$ A rizalitokat kiemelt tetőidomok hangsúlyozták. A homlokzatot három bejárat nyitotta meg, melyeket 1945 után megszüntettek. A délről az első a 'D' jelü államtitkári bejárat a Hess András téri miniszterinek a pandanja volt, az udvar terében kialakított lépcsőházi és lifttoronnyal, illetve a fentebb leírt belső elrendezéssel egyetemben. A középrizalit bal szélén nyílt a 'G' jelü, csúcsíves, gazdagon keretelt, kétszárnyú festett üvegezéssel díszített kapuzat, záradékán függönyíves mezőben magyar címer, fölötte a korona. ${ }^{118} \mathrm{Az}$ emelkedő szintű egykori kapualj hálóboltozata ma is megvan. A harmadik kapu a front végén a Fortuna közi szárny csuklópontja mellett vezetett a III. udvarba.

A díszudvar uralkodó homlokzata a Szentháromság téri szárny északi frontja volt. Öttengelyes, középtengelyben a díszlépcsőház „apszisa”. Alul íves, felül a nyolcszög négy oldalával záródik, két oldalán, a már említett nagyméretü ablakpár. A keleti és nyugati homlokzat jellegzetes eleme a lifttorony mellett, a két lépcsőház emelkedő, lépcsőző ablaksora. Az udvart északról a tizenkét tengelyes C-keresztszárny zárta le. Két szélről számított harmadik tengelyét kiemelték, díszített parapetet és szamárhátíves lezárást kaptak. Az alagsorban a kazán- és a gépház volt elhelyezve. A Királyi Egyetemi Nyomda épülete és a keresztszárny északi homlokzata közé hozzávetőleg háromszög alaprajzú épületrész ékelődött be. Háromkarú lépcsőzetéből a kiszolgáló személyzet szálláshelyiségei voltak elérhetőek.

A Fortuna közi szárny szimmetrikus elrendezésü volt, a homlokzat síkját középtengelyben és a széleken rizalit tette mozgalmasabbá. A baloldali rizalit mellett a Fortuna utcai sarok egy tengellyel bővült, a Fortuna utcai hattengelyes épületszárny zárásaként. A homlokzat képzésmódja megegyezik az Országház utcai szárnnyal. A Fortuna köz középrizalitjában gazdagon tagozott bélletes kapuzat közvetlenül az 1945 után elbontott lépcsőházba nyílt. A keretező falpilléreket fejekkel és a Szent Koronával díszített fiálé zárta le, melyek között a félemeleti pihenő megvilágítását szolgáló nyomott csúcsíves záradékú, festett üvegezésű ablakpár biztosította. ${ }^{119} \mathrm{Az}$ udvar terébe a lépcsőházhoz kapcsolódó udvari középrizalit melletti zugba nyugat felől nyitott orsóterű poligonális csigalépcső torony épült. Pandanja is elkészült az udvar északnyugati sarkában, a folyosók metszéspontjában kialakított térbővületekben a hivatalszolgák tartózkodtak. A kilencszintes irattár ma is eredeti magasságú. Keleti és nyugati hosszhomlokzatai kilenctengelyesek. A vasbeton szerkezetü polcrendszer a struktúra része. Az épületszárny déli végében a háromkarú lépcsőházat építették ki. Tetején egykor a tüzi vizet tartalmazó tartályt helyezték el, amely a nyolcszögletü toronyba volt rejtve. Az irattári szárny északi oldalán helyezkedett el a hivatalszobákat magába foglaló, L alakú, háromemeletes rövid G keresztszárny. Kétkarú lépcsőzete az Országház utcai 'G' bejáratból két oszloppal kialakított térbővületen keresztül volt megközelíthető. (12-13. kép)

Fellner Sándor a Pénzügyminisztérium palotájáért - „az volt a fő törekvésem, hogy hazám formáinak galyát (sic) a régi stílus fájába oltva, azon új hajtást fakasszak" -, az érdem jutalmaként 1905-ben a „toronyi” nemesi előnevet nyerte, s 1906-tól az Országos Középítési Tanács tagja lett. A neve alatt megjelent Albumban - minthogy a palota „közpénzen készült... módot kellett tehát találni arra, hogy a közönség megismerkedhessék építészeti jellemvonásaival" - sajátos módon a vállalkozók, mesterek és cégek nem lettek nevesítve, csupán a költségek. ${ }^{120}$ A Nemzeti Szalon jubiláris tárlatán 1932-ben Fellner a Pénzügy- és Igazságügyi Minisztérium (1912-1915, Markó utca 16.) főhomlokzati rajzaival szerepelt. ${ }^{121}$ Hatvanéves építőmúvészi munkájának elismeréseként a Magyar Építőművészek Szövetségének elnökét az Incorporated Association of Architekts E Surveyors (London) tiszteletbeli tagjává választotta. ${ }^{122}$

\section{JEGYZETEK}

* A Kormány a budai Várnegyed helyreállítását és megújítását célzó Nemzeti Hauszmann-tervvel összhangban, az 1837/2015. (XI. 24.) határozatában foglaltak szerint a Nemzetgazdasági Minisztérium a Budapest I., Szentháromság tér 6 . sz. alatti ingatlanba költözik (viszsza). A Forster Központ elkészítette a volt pénzügyminisztériumi épület kutatási dokumentációját az építészeti tervezés segédleteként. Arnóth Ádám, Balázsik Tamás, Baldavári Eszter, Bazsó Gábor, Bíró László, Bodor Péter, Bodó Balázs, Bódyné Máthé Ildikó, Bozóki Lajos, Csejdy Júlia, Csikai Barna, Fenesi Lívia, G. Lászay Judit, Galamb Zsuzsanna, Gaylhoffer-Kovács Gábor, Győr Attila, Horogszegi Tamás, Mentényi Klára, Nagy Veronika, Pesta
László, Prakfalvi Endre, Sebestyén Ágnes, Velladics Márta: Budapest I. kerület, Szentháromság tér 6. A Pénzügyminisztérium egykori palotájának építéstörténeti tudományos dokumentációja, 2015. november - 2016. január. (Forster Központ Tervtár, 46361 ltsz.) Az építéstörténeti fejezet B. G. - P. E. munkája. Előzmény: Bor Ferenc: Budapest I. Szentháromság tér 6. Tudományos dokumentáció. Hild-Ybl Alapítvány, (FIMÜV 1988) 1997-1998. Budapest Főváros Levéltára [a továbbiakban BFL] Budapesti Müemlék Felügyelőség iratai. XV. 17.e. 306. 252. d.

1 A Ney Ede-kőfaragómúhely (Angyalföld, Máglya u.) kőfaragósegédeinek levele Fellner Sándorhoz, hogy róluk se feledkezzenek meg a falegyen jutalom (a falko- 
rona elérésekor volt szokásban, kb. „bokrétaünnep”) osztásakor. Budapest, Magyar Nemzeti Levéltár, Országos Levéltár (a továbbiakban: MNL, OL), K-487. 3. cs. fol. 798, dátum nélkül (1. 11. jegyzet).

2 Az 1866/67-es tanévben kezdte s a VI. osztállyal zárta az iskolát 1871/72-ben. A Pesti Községi Főreáliskola anyakönyvei, 1866/67-1871/72. BFL, VIII.32.b.

3 A kir. József-Múegyetem tanárai és hallgatói 1851/2-től-1881/2-ig. Budapest 1883, 4., 30. A kiadvány szerint a Pesten 1856-ban (!) született Fellner Sándor építész (!) az 1872/73-as tanévre iratkozott be; abszolutóriumot, diplomát, honosítottat sem szerzett. Vö. A magyar művészet a 19. században, I. Szerk. Sisa Tózsef. Budapest 2013, 338-341.

4 Képviselőházi irományok, 1872. XVIII. k. 795. szám, 416. Az 1857-ben alapított Mûvészeti Alap három ösztöndiját 1873. október 13-án Brzorád Gyula szobrász, Vándory Emil festész (sic) és Fellner Sándor építész nyerte el.

5 Képzőmüvészeti Szemle I. 1879. márczius hó. 44. Vegyes közlemények: „Három fiatal festőnk (!), kik külföldön képezték magokat, a napokban érkeztek vissza Budapestre. Fellner Sándor a történeti irányt műveli s Párizsban Zichy tanítványa volt." Fellner 22 éves ekkor. Az Országos Régészeti és Embertani Társulat 1881. március 29-én tartott ülésén a téma a "magyarhoni renaissance” volt. Fellner Sándor „az esztergomi Bakács kápolnáról értekezett, „melyet minden szempontból átkutatott”, s fölvételeit bemutatta. Pulszky Károllyal közösen jegyzett munkát jelentetett meg a kápolnáról: Bakocs Tamás sírkápolnája Esztergomban. Archaeologiai Értesítő Ú. F. I. 1881, 246-251. Balogh Jolán: Az esztergomi Bakócz kápolna. Budapest 1955, 117, 119, 121., 67-68. kép.

6 Szendrei János - Szentiványi Gyula: Magyar Képzőmúvészek Lexikona, I. Budapest 1915, 478. Fellner hat éven át folytatta stúdiumait külföldön. Vö. Allgemeines Lexikon der Bildenden Künstler, XI. Leipzig 1915, 376. A szócikk szerzője, Lyka Károly - mesternév említése nélkül - Wiener Polytechnikum-beli tanulmányokról ír, Párizzsal kapcsolatban Zichyt említi csupán, s hazatérte óta Fellner hauptsächlich als Architekt müködik. Megoldatlan egyelőre az építészi végzettség kérdése: a „Névjegyzéke mindazoknak akik a m. kir. József Müegyetemen 1928 évi június hó végéig oklevelet, absolutoriumot vagy oklevél honosítást nyertek" (Budapest 1929) című kiadványban Fellner nem szerepel sem az építészek, sem a mérnökök listáján. (Az építészszakosztályba rendes hallgatóul beiktatottak törzskönyvében sem találkozunk Fellner Sándor nevével. Igaz, a ránk maradt I. kötet az 1878/79, 80/81, 81/82. évfolyamokat tartalmazza. Budapesti Müszaki Egyetem Levéltára, 105/d. I. k.) A Magyar Zsidó Lexikon (Szerk. Ujvári Péter. Budapest 1929, 271-272.) szócikke szerint a „,budapesti műegyetemen és a bécsi képzőművészeti akadémián tanult. Azután (1876-1879) Párizsban dolgozott Garnier... mellett." Fellner 16 éves korában, 1873 októberében iratkozott be a bécsi Képzőművészeti Akadémiára, ahol 1876 júliusáig az építészeti szakosztályban Th. Hansen tanítványa volt. Fleischer Gyula: Magyarok a bécsi Képzőművészeti Akadémián. Budapest 1935, 41. L. még Kempelen Béla: Magyar zsidó családok. (1937-1939, reprint 1999) III., 97. Sisa József: Magyar építészek külföldi tanulmányai a 19. század második felében. Művészettörténeti Értesítő XLV. 1996, 171-172, 184.

7 Budapest, Forster Központ, Budapesti müemléki topográfiai adatbázis. Sisa József: kastélyépítészet és kas- télykultúra Magyarországon. A historizmus kora. Budapest 2007, 259-261. (Felsősegesd)

8 Vasárnapi Ujság XL. 1893/8., 122. Az új államtitkárok. 9 Vasárnapi Ujság XLII. 1895/7., 105. Két új államtitkár.

10 T. Fellner Sándor: A Magyar Királyi Pénzügyminisztérium Palotája. Budapest 1908, 2. (a továbbiakban: Album 1908); "v": A M. Kir. Pénzügyminisztérium Palotája. Művészet VIII. 1909, 204-206. Magyar művészet, 1890-1919. Szerk. Németh Lajos. Budapest 1981, 63; A historizmus művészete Magyarországon. Szerk. Zádor Anna. Budapest 1993, 60., 264-265. A minisztérium korábbi épületeire: Siklóssy László: A Fővárosi Közmunkák Tanácsa története. Hogyan épült Budapest? (1870-1930) Budapest 1931, 335-337, 374-375; Horler Miklós: Budapest műemlékei, I. Budapest 1955, 356-358, 588-590.

11 Források: MNL, OL, Pénzügyminisztériumi Levéltár, Elnöki iratok, K-255. 1115. cs., fol. 1-922, 1116. cs., fol. 1-5, tervek: módosított építési engedély 143210/1903-III. (júl. 23.) tanácsi szám, 1117 cs., fol. 1-745. Pénzügyminisztérium épülete Építési Bizottságának iratai, K-487. 1-5. cs., az u. n. 6. cs. az Epítési napló I. k.: 1901. X. 5-1902. X. 21. (a továbbiakban: MNL, OL, állag, csomó, fólió) BFL, XV. 17. d. 329. Építési ügyosztályok tervtára, hrsz. 6590, 540-541. doboz, fol. 1-230, 1885-1991. [továbbiakban: BFL, Építési ügyosztályok tervtára (a továbbiakban: É. ü. t.), doboz, fólió] Az 52468/1901-III. (aug. 6.) tan. számú engedélyezési tervsorozat hiányos; fol. 13-24: Fellner Sándor irodájából 1901. VII. 9., az építész és Majorossy Géza építőmester kézjegyével ellátva. Alaprajzok, 540. d. fol. 13-18, helyiség számozással.

12 Album 1908, 2.

13 MNL, OL, K-487. 1. cs. ÉB 2/1901. fol. (1-12) 7-8. kivonat a minisztertanács 1901. I. 11-i ülésének jegyzőkönyvéből. Felmerült, hogy az új palota a Verbőczy (Táncsics M.) utcában fekvő József-laktanya és a szomszédos Zichy-palota telkén épüljön, de ezt a megoldást költségvetési okokból elvetették. (A József és a Bécsi kapu [téri] laktanyát használta az építkezés alatt ideiglenes jelleggel a minisztérium.) Az építési telek szabályozásának Fodor István készítette térrajza; 42 XXII/8b ttsz-on 1901. III. 12-i dátumú, uo. fol. 9.

14 MNL, OL, K-487. 1. cs. ÉB48/1901. fol. 150-155.

15 Ezrey [Komor Marcell]: Az elaludt mozgalom. Vállalkozók Lapja XXII. 1901, I., 30. 1-2. „Sablonos gótikát” tehetséges hazai pályakezdőink is tudnak, jegyezte meg maliciózusan a cikkszerző. Vö. Az 1901. évi október hó 24-ére hirdetett Országgyülés képviselőházának naplója. V. kötet. Budapest 1902, 336. (91. ülés 1902. április 15-én)

16 MNL, OL, K-487. 1. cs. ÉB 7/1901. fol. 26-31. 1901. I. 21. Az iratra rávezették: „Ezen észrevételek (ti. Zobeléi) a szükségeshez képest az építkezésnél figyelembe vétetvén" - ad acta, Bp. 1902. július. Vö. ÉB 49/1901. jkv., 1901. VI. 13. ÉB ülés, fol. 154-155. Fellner már módosította is tervezetét annak függvényében, hogy az Egyetemi Nyomda épületének „megvételétől el kellett tekinteni”.

17 MNL, OL, K-487. 1. cs. fol. 32. Kisajátítási ügyekben a pénzügyminisztert br. Podmaniczky Frigyes az FKT alelnöke képviselte. Az ügyek egy része az építkezés megkezdése után zárult le. Vö. ÉB 1902. VI. 12-ei ülés: a "kisajátítási ügyek még mindig nincsenek befejezve"! K-487 3. cs. fol. 647-649 és passim. Az Országh, Harrer és Vranovics féle ingatlanokról (2221, 2218, 2214, régi hrsz.) volt szó. Az elbontott épületekre 1. Horler Miklós: Budapest müemlékei, I. Budapest 1955, 580-586. 
18 MNL, OL, K-487. 1. cs. fol. 46. Az eredmény nem ismeretes.

19 MNL, OL, K-487. 1. cs. ÉB 16/1901 fol. 53; fol 64.

20 MNL, OL, K-487. 1. cs. ÉB 23/1901 fol. 67. A szerződés tervezet szerint (1901. I. 31.) Fellner tiszteletdíja az előirányzott 3 millió K építési költség 4\%-a. Az összeg egynegyede (1\%) a tervezés és múvezetés „szellemi munkája", a fennmaradó rész (3\%) pedig a művezetéssel járó összes készpénzes kiadás, irodai személyzet fizetése stb. Az ütemezésre vonatkozóan rögzítették: 1; a szerződés aláírása $(9000 \mathrm{~K}), 2$; a tervezet és költségvetés bemutatása (12 $000 \mathrm{~K}), 3$; az első emeleti övpárkány elérése (16 000 $\mathrm{K}), 4$; a „fedélzet” felállítása (20 $000 \mathrm{~K}), 5$; a külső vakolat elkészülte (20 000 K), 6; a belső munkák befejezése (20 000 K). Fellner javadalmazásába beleszámolták a minisztérium megbízásából 1900-ban tett tanulmányút költségeit. K-487. 5. cs. fol. 756-760. Az építész magyar nyelvű autográf levélben tájékoztatta 1901. július 11-én az ÉB elnökét, hogy a beérkezett vállalkozói ajánlatok alapján az előzetes kalkulációnak megfelelően az építési költség $3031000 \mathrm{~K}$ lesz, tehát a honorárium számításának ez az alapja, s: „A mennyiben velem parancsol óhajtani rendelkezésére állok." fol. 754. (Az építészi munkálatok érvényes díjszabályzatát a Magyar Mérnök és Építész Egylet 1892. évi május 7-ikén tartott 342 választmányi ülésén fogadták el. Uo. fol. 773-774.) Az „előkészítő” irat, Fellner „,ajánlata” Lukács Lászlónak január 5-én született. Uo. fol. 761-762, (az ajánlat vázlata, 1901. január. fol. 770-772).

21 MNL, OL, K-487. 1. cs. fol. 143., fol. 79-80. Árlejtési hirdetmény. Budapesti Közlöny 1901. VI. 13. 6.

22 MNL, OL, K-487. 1. cs. ÉB 42/1901. fol. 121-122. (1901. VI. 24.) fol. 143. (1901. VII. 11.) és fol. 318. (VII. 13.) Fellner illetékességből a Kereskedelemügyi Minisztériumba is elküldött egy "teljesen felszerelt" tervsorozatot (1901. VI. 26.): 1 helyszínrajz, $18 \mathrm{db}$ alaprajz, 5 metszet, 4 homlokrajz és statikai számítások, uo. fol. 123.

23 MNL, OL, K-487. 1. cs. fol. 325-326. Vö. 11. sz. jegyzetben hivatkozott BFL tervsorozat, alaprajzok, metszetek. A belvilág $280 \mathrm{~cm}$-re csökkentése eredményeként (irattár) egy szintet „megspóroltak”. K-487. 5. cs. fol. 753-754. (1901. IV. 18.)

24 MNL, OL, K-487. 1. cs. ÉB 6/1901. fol. 22-25., mellékelve a Vállalkozók Közlönye 1899 (V.) VII. 11. Kompakt födémekről Breymann szabadalma szerint (Klny. vö. Nagy Virgil: Vasbeton födémek. Magyar Mérnökés Építész-Egylet heti értesítője XVIII. 1899, 141-143. A Monier, mint a legrégebbi, a Mátrai és a Rabitz födémek összehasonlítása). Csatolva egy irat, mely szerint Budapest Székesfőváros Tanácsa engedélyezte (19071/1899III.), hogy a Lipótvárosban az Alkotmány-Szemere utcák sarkán a Budapesti Kereskedelmi és Iparkamara által építendő épületre a Breymann-féle szabvány kompakt födémet alkalmazza a Magyar Monier Építési Vállalat. Az irattári állványzat metszetrajza a padozattal és talplemezzel. K-487. 5. cs. ÉB 421/1903. fol. 227. BFL XV. 17. d. 329.6590 hrsz. 540. d. fol. 22. Irattár metszet, $M=1: 20$, 1901. VII. 9. (ép. eng. 52468/1901-III.) 541. d. fol. 69. Irattár vasállványzatának részletterve. Lépték 1:10. A Monier és a gipsz pallószerkezetekre - ez utóbbi Wayss G. A. szabadalma volt, melyhez beton helyett marhaszőrhöz kevert gipszet használtak - 1. még: Magyar Mérnök- és Építész-Egylet Közlönye XV. 1891, 18-28, 66-81.
25 MNL, OL, K-487. 1. cs. fol. 107-109.

26 Szerződések: MNL, OL, K-255. 1115. cs. fol. 2-620, K-487. 1. cs. fol. ÉB 89/1901. fol. 445-506 és passim. Majorossy benyújtott költségvetéséből kiderül, hogy a szükséges helyeken nagyhordképességü iszapolt pillértéglát, a vastartók közötti boltozatoknál ún. ónhorgany téglát használ majd. A boltozatfelület (extrados, bolthát) pedig hidraulikus mészhabarccsal lesz kiöntve. Az elhelyezési munkák közül megemlítendő, hogy 218 db 4 négyszögméternél nagyobb ablak és ajtótok volt tervbe véve (fol. 456-459, 1901. VIII. 31.). Vállalkozók maguk is bejelentkeztek; Pick Ede a saját gyártmányú, 'Zenith', légnyomás nélküli, zajtalanul múködő hydraulikus ajtócsukó rendszerét ajánlotta. K-487 1. cs. ÉB 69/1901. fol. 349-353. A központi fütés és szellőzés, ácsmunkák és Irattár fedémei, fedémszerkezetei, állványzata betonból, K-487, 1. cs. ÉB 91/1901. (nov.) fol. 510-570. Árlejtési hirdetmény; Vállalkozók Lapja 1901. X. 9.

27 BFL, XV.17. d. 329. 6590 hrsz. 541. d. fol. 43-45. (1902. június) ép. eng. sz.: 143210/1903-III. (VII. 22.)

28 MNL, OL, K-487. 6. cs. Építési Napló, 1902. IV. 2-ától folyamatosan. Egy kétoldalas ív a naplóban az alábbi rovatokat tartalmazta: dátum, időjárás, munkások száma, dolgoztatott (munkavégzés), minták és anyagok bírálata, építésvezetőség rendelései, vállalkozók rendelései, irat, rajz, észrevétel. (Majorossy helyett a naplót rendre Kunfalvi Nándor építőmester írta alá.)

29 MNL, OL, K-487. 1. cs., ÉB 93/1901. fol. 581-711, (sématáblák: uo. fol. 591-593, 601-604, valamint K-255. cs. 1117. fol. 517. idomvas-ablakok, 537-541. szobrászmunkák pyrogránitból, költségvetés és tájékoztató ábrák, 558-577. asztalosmunka feltételei, költségvetése és tájékoztató ábrái, 578., bádogosmunka tájékoztató tablója; 39. rajz a rézvitéz). ÉB/157. 1902. X. A (kő)szobrász munkákra a szerződést Langer Ignácz (1901. XI. 18.), a bádogosra a Boross testvérek nyerték el. (1902. VI. 24.) Egy levéltervezet szerint Lukács pénzügyminiszter elhárította volna Hegedüs kereskedelemügyi miniszter közbenjárását (1901. X. 11.), azzal, hogy pl. Dévai trachitot használnak az építkezésen; így a „hazai kőbányák érdekeire tekintettel voltam". (1902. VI. 15.) uo. fol. 705-710.

30 MNL, OL, K-255. 1115. cs. fol. 17-18. Déry Attila: Az építészeti eklektika anyaghasználatának kérdéséhez. In: Gerő László nyolcvanötödik születésnapjára. Szerk. Pámer Nóra. Budapest 1994, 405.

31 Grünwald szerződése, MNL OL K-487. 5. cs. fol. 750, a bontás kezdete: 1901. VII. 24. K-487. 1. cs. fol. 354358. 1901. VIII. 12., ÉB 94/1901. fol. 702-704. A vállalkozó a kinyerendő anyagért $5560 \mathrm{~K}$-t ajánlott meg.

32 MNL, OL, K-487. 6. cs. Építési Napló: X. 5.: E-, F-, XI. 6.: G-, C-, XI. 7.: D-szárnyak kitüzése történt meg. A napló első ívlapján, az épületkontúron feltüntették a szárnyak, udvarok és rizalitok azonosítását biztosító betü- és számjelzéseket; ezeket használjuk. (A hatóságok az Elnöki épületben az átalakítási munkálatokat engedély hiányában betiltották, X. 7-11.)

33 Album 1908, 6. és Építési Napló.

34 Hornyánszky a nyomtatványok 128 K-ra rúgó számláját 1902. III. 21-én nyújtotta be. MNL OL K-487. 4. cs. ÉB 216/1902. fol. 233-238. Napló, 1902. IV. 15.; Fellner autográf bejegyzése.

35 Album, 1908. I. tábla [t.] Az Egyetemi Nyomda irattári szomszéd falának átalakítási tervezetét Reischl 1902. III. 
4-én láttamozta. MNL, OL, K-255. 1115. cs. fol. 773-779. vö. Építési napló 1902. I. 30. (28-29. ív) Az Egyetemi Nyomda irattári szomszédfalának átalakítási tervezete. Látta Reischl, művezető építész, építési ellenőr, 1902. III. 4-én.

36 BFL, É. ü. t. (l. 11. j.) 540. d. fol. 17. III. emeleti alaprajz (1901. VIII. 6.)

37 Minden tárgyat háromszor kellett olajmázzal lekenni, mely máz óloméleggel (Bleiglätte) fözött lenmagolajból és lisztfinomságra őrölt festékanyagból készült. K-487. 3. cs. ÉB 150/1902. fol. 1-235

38 BFL, É. ü. t. (l. 11. j.) 541. d. fol. 19-20. A-B és C-D metszet.

39 MNL, OL, K-487. 6. cs. Építési Napló. A legtöbb nehézség az alapozásnál a kazánház és az Irattár alapfalainak kereszteződésében adódott, a levert cölöpök 18 m mélységben is sárban, iszapban álltak. A cölöpökre száraz falazat került, melyet másfél méter vastag vasalt betonréteg fed; „ennek másfél méter hosszú kulcsai a sziklára épített szomszéd falba kapaszkodnak, s e fal nyomása által merevíttetnek". Album 1908, 7., I. és IX. t.

40 MNL, OL, K-255. 1115. cs. fol. 274-275. 1902. VII. 9. A pirogránit és terrakotta munkák leszállításának határideje a rajzok átvételétől számított 3 , a majolikáké 4 hónap volt. A lépcsőház apszisába $8 \mathrm{db}$ apród és nemes kisasszony alak készült, Zsolnay mázas (émail) pirogránitjából. Medvey Lajos: Vezető Budapest szobrai megtekintéséhez. Budapest 1939, 15.

41 MNL, OL, K-487. 1. cs. ÉB 74/1901. fol. 421. Az Államvasutak Gépgyára szállított vasszerkezeteket 1 . BFL, É. ü. t. (1. 11. j.) 540. d. 43-45 és 541. d. 46-99. folióig. A fedélszerkezetben csak a könyvtár fölötti rész (A-szárny) főszaruzata készült vasból, szegecselt vastartókból. Album, 1908. 7.

42 MNL, OL, K-487. ÉB 76/1901. fol. 423-426.

43 Langer referencia munkái; Mátyás-templom, Milleniumi történelmi csoport, Párizsi világkiállítás magyar pavilonja (1900). MNL OL, K-255. 1115. cs. fol. 93-95, a szerződése 1901. XI. 18-án kelt. K-487. 2. cs. ÉB 109/1901. XI. fol. 77-78. (Az épület kismintájának számlája, előzmény: ÉB 39/1901.)

44 MNL, OL, K-487. 2. cs. 105. ÉB/1901. fol. 9-71, K-255. 1115. cs. fol. 108-113.

45 BFL, É. ü. t. (1. 11. j.) 540. d. fol. 39. fsz. módosított alaprajza ép. eng. 143210/1903-III. (VII. 22.), 541. d. fol. 48., 50.

46 MNL, OL, K-487. 2. cs. ÉB 107/1901. (XI. 15.) fol. 74-75. Az építési naplóba november 20-án jegyezték be az egyeztetett tervváltozásokat a 8. íven. (Helyiségszámozott alaprajz, BFL, É. ü. t. (1. 11. j.) 540. d. fol. 14.)

47 Breymannék 86000 koronás ajánlata MNL, OL, K-487. 2. cs. fol. 510-512. A Breymann-féle szabadalmaztatott kompakt-födém statikai számítását 1. uo. 4. cs. fol. 614-624 (1903. VII. 2.) Vállalkozók Lapja 1891. 3. 3. Merényi Ferenc gyújtése Forster Központ, Magyar Építészeti Múzeum.

48 A Hazai Vasbeton Építési Vállalat Mátrai, Gfrerer és Grossmann födémnek, a nyertes Breymannékkal szembeni olcsóbb voltának számítása, 1. MNL, OL, K-481. 1. cs. fol. 436-438. 1901. IX. 7. Breymannék 94000 koronás ajánlata; K-487. 2. cs. fol. 510-512. (1901. XI. 5.) Mátraiék a miniszternél fellebbeztek arra hivatkozva, hogy Fellner két olyan szempontot érvényesített a bírálatkor, ami kizárta a Mátrai-féle szabadalmazott födémet - csak portland cement használható és a maximális mezőszélesség $220 \mathrm{~cm}$-, holott egy másik pénzügyminisztériumi építkezésen, Temesvárott a M. Kir. Dohánygyár szárnyépületén épp ezt a födémrendszert építik be, 1901. IX. 7. A Mátrai-féle vasbetonszerkezetekre 1. Budapest müszaki útmutatója. Szerk. Edvi Illés Aladár. Budapest [1896,] 577. A szerkezetben a beton csak „,kitöltő szerepet játszott, a teherhordásban nem vett részt"! Gombos Mihály: Vas- és vasbetonszerkezetek. In: Technikai fejlődésünk története. Szerk.: Orphanides János et al. Budapest 1929, 468. (Nay és Strauss a Weiss Lajos szabadalmát képező, ún. recontra téglákból készült síkfödém ajánlata, uo. fol. 439.)

49 Betonfedémek iratanyaga MNL, OL, K-487. 2. cs. ÉB 126/ 1902. fol. 294-323. 1902. március. A Moebers-Melocco-féle szabadalmazott concret bordás vasbeton födém leírása és referenciák, uo. fol. 314-322. A gyulafehérvári tiszti laktanya 5., 6. sz. épületnél, (1900/1901), 1600 négyzetméter került abból beépítésre. (Kiss Jenő Wünsch Róbert jogutódjaként pályázott sikertelenül. A Wünschféle boltozatos szisztémára 1. Magyar Mérnök- és ÉpítészEgylet Közlönye XXIV. 1890, 221-232. Solt község 10 méteres, kétnyílású „parabolás” vasbeton hídja.)

50 MNL, OL, K-487. 2. cs. Melocco 118500 koronás ajánlata, fol. 481-494, az Hennebique-rendszer mint alternatíva uo. fol. 496-508. Zielinski támogató nyilatkozata az 508. fólión. Budapesti Közlöny 1901. X. 16. 13. oldalon tette közzé a központi fútés és szellőztetés, ácsmunkák, az irattár födémei, fedélszerkezete és iratállványok szállítása betonból - árlejtési hirdetményét: MNL, OL, K-487. 1. cs. ÉB 91/1901. fol. 511-513. K-487. 2. cs. ÉB 145/1902. május, fol. 456-536 Központi fütés és szellőztetés K-487 2. cs. 115 ÉB/1901. dec. (6.) K-487. 2. cs. 109. ÉB 1901. fol. 77-78. K-487. 2. cs. fol. 109-225, elszigetelő és aszfalt (asphalt) munkák ÉB 119/1902. fol. 236-290.

51 MNL, OL, K-487. 2. cs. ÉB 131/1902. fol. 338-341. A földszinti falegyent 1902. V. 14-én érték el. Uo. fol. 452. 52 MNL, OL, K-487. 3. cs. fol. 645.

53 MNL, OL, K-487. 3. cs. ÉB 152/1902. fol. 681. 1902. VII. 5. K-487. 2. cs. 131. ÉB/1902. fol. 338-341. I. sz. részszámla az alapozási munkálatokról.

54 MNL, OL, K-487.3. cs. ÉB 191/1902. VII. 31., fol. 790800, K-487. 4. cs. fol. 9-17., 8800 koronát osztott ki, Reischl Ferenc müszaki ellenőr Schlosser Alajos főpallérnak 1500 K-t, Blastik József építész művezető ugyanannyit, három anlegoló kőmüves à $20 \mathrm{~K}-\mathrm{t}$, egy 2. osztályú $6 \mathrm{~K}-\mathrm{t}, 16 \mathrm{I}$. osztályú kőmüves $5 \mathrm{~K}$-t kapott fejenként, 29 asszony és napszámos 2-2 K-t vihetett haza. K-487. 4. cs. fol. 9-16. vö. 1. jegyzet: műhelyben dolgozó három kőfaragó 18 K-át kapott összesen és általányban még kőfaragók 100at. MNL, OL, K-483. 3. cs. fol. 793. (1902. IX. 10.)

55 Előzmények; a $38 \mathrm{~m}$ helyett $40 \mathrm{~m}$ magasságú kémény építésére: MNL, OL, K-487. 2. cs. ÉB 141/1902. fol. 433-448., fol. 454-455. Süss Hermann és társa villámhárítójával felszerelve. K-487. 3. cs. ÉB 190/1902. fol. 789.

56 MNL, OL, K-487. 4. cs. fol. 20-29, 205-207. 1902. XII. 1., ÉB 313/1903. fol. 614-621. vö. Én 1902. VIII. 18-i és 22-i bejegyzést a 130. íven. A szabadalom szerint 1:3:4 volt az ajánlatban, emlékeztetett Melocco.

57 MNL, OL, K-487. 4. cs. fol. 33-35, 68 .

58 MNL, OL, K-487. 4. cs. fol. 4-5. A „villamvilágítási vezeték berendezési munkálatok" iratai, K-487. 4. cs. fol. 74-129. A szerződést a Hirschl és Társa céggel 1903. I. 15- 
én kötötték meg. Az építkezés kezdetén a világítást gázra tervezték. Az A-szárnyban a főlépcsőház, valamint a miniszter, az államtitkár és az elnökség terei kaptak volna villanyáramot.

59 MNL, OL, K-487. 4. cs. fol. 42-43. 1902. X. 30. Forgó és Társa ajánlata nyert.

60 A helység azonosítását - Valkány - Ódor Jánosnak köszönjük. Torontál vármegye. Szerk.: Borovszky Samu. Budapest é. n. [1911,] 135. és 129, fénykép: Schwarz Lajos kastélya Simonpusztán.

61 MNL, OL, K-487. 4. cs. ÉB 219/1902. fol. 134-137.

62 MNL, OL, K-487. 4. cs. fol. 186-187. (1902. XI. 24.)

63 MNL, OL, K-487. 4. cs. ÉB 219/1902. fol. 226-227, 1902. dec. 19.

64 MNL, OL, K-487. 4. cs. ÉB 254/1903. fol. 327-328., a plusz $4000 \mathrm{~K}$ igényt jóváhagyták. (A rézvitéz vázlatrajza; K-255. 1117. cs. fol. 578.) Borossék a nyomásgyakorlás eszközével is éltek megelőzően, mondván, emelkedni fog a réz ára a piacon. Uo. fol. 248. (1903. I. 8.)

65 MNL, OL, K-487. 4. cs. fol. 337. (III. 10.) Fellner jelentése Graenzenstein Bélának. Biebel János oraviczai építész elfogadta a Graenzenstein által kívánt tízévi jótállást a B-, D-, E-, G-lépcsőházak lépcsőfokainak anyagára vonatkozóan úgy, hogy a letett biztosítékához három év múlva hozzájusson, és a további hét évre pedig összes vagyonával felelne.

66 MNL, OL, K-487. 4. cs. fol. 256. 1908,7

67 Építési napló MNL, OL, K-487. 4. cs. fol. 328. Album

68 MNL, OL, K-255. 1115. cs. fol. 604-605, 618. (1903. XI. 1., 1904. I. 25.) A homlokzatok lábazata dévai szürke trachit és almási fehér mészkő, a főhomlokzaton besztercebányai és biai követ dolgoztak fel. Fagyálló kemény mészkőből készültek a fedlapok, főpárkányok, könyöklők, toronybordák, krabbák. A lépcsőházakban Fellner bács-dorogi (Erdély) finomszemcsés homokkövet használt, predeti márványból és homokkőből valók a lépcsőfokok. A főlépcső 4-5 méteres fokai és könyöklői s a két kandeláber oraviczai, illetve ruszkiczai fehér márványból készültek, utóbbi márvány fedi az előcsarnok szegecselt oszlopait is. Album 1908, 7.

69 MNL, OL, K-487. 4. cs. fol. 545-546.

70 Medvey Lajos: Vezető Budapest szobrai megtekintéséhez. Budapest 1939, 15. Langer Ignác (VIII. Conti u. 22.) 1904. II. 1-jén kérvényezte Graenzensteinnél plusz költségeinek megtérítését. A költségvetés 1. tétele ornamentikát írt elő; „,helyébe más művésziesebb kivitelű aczképek (portrait) készültek". MNL, OL, K-487. 5. cs. fol. 220-221.

71 Album 1908, 6.

72 MNL, OL, K-487. 4. cs. fol. 499. Ekkortájt rendelték meg a folyosókon és szobákban felszerelésre kerülő csillárhorgokat.

73 A „világhírű Schmidt Frigyes cs. k. építészeti főtanácsos", aki 1876 tavaszán a Mátyás-templomot megvizsgálta, és annak további kiépítésére szakvéleményt adott, mely szerint a torony lezárása a rajta „,szemlélhető hajógerincz alaku ívdíszítmények által követelt mérsékelten emelkedő csúcsba végződő félgömb kősisakkal, mely hasonlítana a Bécsben létező Maria am Gestade czimü templom eredeti gót tornyához" volna indokolt. Németi Németh Lajos: Nagyboldogasszonyról nevezett Budapestvári Főtemplom történelme. Esztergom 1876,
222-223. Vö. Mátyás-templom. Kiállítási katalógus. Szerk. Farbaky Péter et al. Budapest 2015, 340-341. (7.18. tétel: Déli homlokzat, vázlat. [Farbakyné Deklava Lilla]). Marosi Ernô: Gótikus és neogótikus kupolák. In: Romantikus kastély. Tanulmányok Komárik Dénes tiszteletére. Szerk. Vadas Ferenc. Budapest 2004, 356-363. Nehr Sándorra 1. Pereházy Károly: Mưvészi vasmüveseink a nagyvilágban. Uo. 472-477.

74 MNL, OL, K-487. 4. cs. ÉB 258/1903. (március) fol. 342-370. Az elnöki (miniszteri), illetve államtitkári termek, az előcsarnok és főlépcsőház szobrász és díszítő munkáira Langer ugyan ezer koronával többet kért, mint Vögerl (19500 K), de a javaslat szerint őt kell megbízni, mert elvállalja a konkurencia ajánlati árán is a munkát, valamint dolgozott és bizonyított is már az épületen. Uo. fol. 600-603. (1903. VI. 17.)

75 MNL, OL, K-487. 4. cs. ÉB 261/1903. (március) fol. 461-467. A kőpadolási munkák kivitelezésének tekintetében a vállalati feltételek rögzítették a $20 \times 20 \times 2,2 \mathrm{~cm}$-es mozaiklap méretet, a cementlapok színezéséhez csakis tartós ásványfesték volt használható, miként a granitto terazzóhoz is kizárólag márványtörmelék. K-255. 1117. cs. fol. 703-704.

76 MNL, OL, K-487. 4. cs. ÉB 259/1903. fol. 371-410.

77 MNL, OL, K-487. 4. cs. ÉB 313 (1903. júl. fol. 614624. A számítás 1903. VII. 2-án készült.) Breymann-ék 1902. III. 15-én keltezett Memorandumukban lobbiztak az irattári megbízatás elnyeréséért, minthogy a fóépület födémszerkezetére vonatkozó vasszerkezet ajánlatuk nem nyert. Arra hivatkoztak, hogy a vonatkozó pályázati kiírás a cég előmunkálatán nyugszik. Különben sincs munkájuk, a Királyi Zálogháznál épp befejezik az építést. A „folyamodó ajánlata elfogadtatván... az irattárral megbizattasson" - ad acta. K-487. 3. cs. fol. 666-668.

78 MNL, OL, K-487. 4. cs. ÉB 323/1903.

79 MNL, OL, K-487. 4. cs. ÉB 324/1903. (VIII. 12.) fol. 644-655. Az ólom kilogrammja 42 koronába került. Számlák az 1903. II. negyedévben szállított anyagokról. K-487. 5. cs. fol. 259-273 (1904. II. 12.)

80 MNL, OL, K-487. 4. cs. ÉB 326/1903.

81 MNL, OL, K-487. 4. cs. ÉB 333/1903. fol. 668. 1903. VIII. 6. K-255. 1117. cs. fol. 245. (1903. VIII. 1.) Az építkezés kezdetén felmerült, amennyiben létesülne hazai linóleumgyár, a folyosókon ezt az anyagot alkalmaznák. K-487. 5. cs. fol. 753., 755.

82 MNL, OL, K-487. 5. cs. fol. 2. Az épület körüli utcák rendezéséhez még 1. K-487. 4. cs. fol. 578. 1903. VI. 9. Az épület körüli csatornahálózat és járda elkészítése is az év nyarán „lakhatóvá" váló palotát szolgálta ki. Uo. ÉB 245/1903. I. 23., ÉB 246/1903. II. 5. (fol. 243-247.)

83 MNL, OL, K-487. 5. cs. fol. 10-11. A toronysisak módosított mintája 1903. II. 2-re készült el. K-487 4. cs. fol. 499. (vö. K-487. 3. cs. ÉB 155/1902.)

84 MNL, OL, K-487. 4. cs. fol. 624, az ajánlatot elfogadták, a teljesítést 1904 tavaszára írták elő. Album, 1908. III. és X. tábla. Egy mellszobor is állt a kertben.

85 MNL, OL, K-487. 5. cs. fol. 13-19. 1903. IX. 11. BFL, É. ü. t. (1. 11. j.) 540. d. fol. 22. Irattár metszete; a 3., 6. és 9. födémszint $16 \mathrm{~cm}$ vastag, a közbülsők $12 \mathrm{~cm}$-esek a tervlap szerint. Fol. 69.: a vasállványok részletterve, lépték 1:10.

86 MNL, OL, K-487. 5. cs. fol. 108. (1903. XI. 9.) 
87 MNL, OL, K-487. 5. cs. ÉB 389/1903. fol. 117-125. 1903. XII. 22.

88 MNL, OL, K-487. 5. cs. fol. 165-166. Egyes leszámolási tervlapok (és számlákhoz csatolt tervlapok). K-487. 4. cs. ÉB 251/1903. fol. 290-302.

89 MNL, OL, K-487. 5. cs. fol. 289.

90 MNL, OL, K-487. 5. cs. fol. 207-219., 275-276. Egy a Fellner-irodából ide került költségvetés szerint Hochmann készíti Strasser Sándor Bábipusztán, Nyitra mellett építendő kastélyához a vasalatokat. (1904. II. 20.)

91 MNL, OL, K-487. 5. cs. fol. 399. 1. még: fol. 519-520., 1905. II. 20. Zilzer igényét méltányolták.

92 Vasárnapi Ujság LII. 1905/4, 49-50. MNL, OL, K-255. 1115. cs. ÉB 397/1903. fol. 914., 1117. cs. fol. 356., á 2000 K. Album 1908, XX. XXI. t. A Tanácsterem. (XXV. t.) A radiátor feletti párkányon a Pannóniában 193-ban császárrá kikiáltott Septimius Severus (?) márványból faragott büsztje áll. Schmidt Miksa ugyanis szállított belőle 2 db-ot, à 825 K-ért. Uo. fol. 88-95, 1905. augusztus 17. Fiziognómia alapján inkább Vespasianus lehet: Pecunia non olet! Ugyanekkor a két „Zsolnay eosin váza kék tiffani fémes színben (Julius Caesar)" csupán 180 K-ba került.

93 MNL, OL, K-485. 5. cs. fol. 358-360. (1904. VI. 9.)

94 MNL, OL, K-255. 1117. cs. fol. 611.

95 Az Országház utcai utolsó kapunál volt a kéthelyiséges posta. Berendezése 1903 második felében történt; wertheim szekrény és $6 \mathrm{db}$ thonet szék $(33 \mathrm{~K})$ mellett a Fischer László cégtől 4 köpőcsésze $(6 \mathrm{~K})$ is kihelyezésre került. MNL, OL, K-225. 1117. cs. fol. 132-138., 146-147.

96 Album 1908, 7. Az okmányok elhelyezése 200 koronába került. MNL, OL, K-487. 5. cs. ÉB 373/1903. fol. 71-72.

97 MNL, OL, K-255. 1117. cs. fol. 69-74. Schmidt $2 \mathrm{db}$ mahagóni könyvszekrényt szállított a fogadóterembe, rajz szerint à 1000 K, 1905. I. 23. Album 1908, XXIV. t. Thék többek között a nagy tanácstermet bútorozta. A nagy elnöki karszékhez 36 üléstermi szék is tartozott „,finom bőrrel kárpitozva rajz szerint", fol. 42-48. (1906. VIII. 7.) Album 1908, XXV. t.

98 MNL, OL, K-255. 1115. cs. fol. 780. A törölközőket és a szőnyegvédőket Wein Károly késmárki mü- és mechanikai szövödéje szállította. K-255. 1117. cs. fol. 361. (1904. III. 14.)

99 MNL, OL, K-255. 1117. cs. fol. 686-687. A használhatási engedélyt IV. 18-án adták ki, uo. fol. 804

100 MNL, OL, K-487. 5. cs. ÉB 566/1905. fol. 644646. (A gipszminta februárban volt kész, fol. 514.) Album 1908, XXIII. tábla. Müvészet VIII. 1909, 206.

101 Müvészet VIII. 1909, 206.

102 Hauszmann Alajos: A budapesti igazságügyi palota. Budapest 1901, 8. A Kúriát díszítő portrék közül mintegy 30 db az 1950-es években Fővárosi Képtárba került, ezekből 15 kép jelenleg a Kiscelli Múzeum állandó kiállításán látható. 103 MNL, OL, K-255. 1117. cs. fol. 228. A világítótestek utó-felülvizsgálata 1907-ben és 1909-ben is zajlott. Magyar Fém- és Lámpaárugyár, Kissling Rudolf és Fia cég, uo. fol. 13-41.

104 MNL, OL, K-487. 5. cs. fol. 725-736. Az irattár hullámlemezes fedélszerkezetére BFL, É. ü. t. (1. 11. j.) 541. d. fol. 78 .

105 MNL, OL, K-487. 5. cs. fol. 745-746. Blastik „a fedél egyen elérése alkalmából aránylag igen szerény jutalomban részesült (vö. 54. jegyzet) azon a czímen, hogy az építkezés befejeztével fog bővebben recompensatiot nyerni" - emlékeztetett Fellner.

106 Az új palota „lakói”-ról, az ügyosztályokról és a létszámokról (segédszemélyzet nélkül) tájékozódás nyerhető: Magyarország Tiszti-Czim és Névtára, XXIV. 1905. Budapest 1905. A Magyar Kir. Pénzügyministerium tíz évi működése 1895-1905. Budapest 1905, 431-432.

107 MNL, OL, K-487. 5. cs. fol. 743. Majorossy egyes leszámolási tervlapjai; K-487. 4. cs. fol. 290-302. (1904. VII.) Scholtz Róbert mázoló munkáinak felülvizsgálatát ugyanaznap végezték el. Uo. fol. 742.

108 MNL, OL, K-487. 1117. cs. fol. 164. (1907. XI. 30.)

109 BFL, É. ü. t. (1. 11. j.) 541. d. fol. 103., ép. eng. sz.: 138030/1918-III. Nem épült meg. Az Egyetemi Nyomda épületének udvari szárnyait 1942-ben bontották el, a Hess András téri középkori eredetü házat ekkor már a Pénzügyminisztérium használta. Uo. fol. 105.

110 Rados Jenő: Műemlékjellegü épület helyreállítása a Várban. Magyar Építőművészet I. 1952, 1. sz., 20-23. Az épületben 1954-1981 között a Budapesti Müszaki Egyetem kollégiuma működött, ezt követően az Új Magyar Központi Levéltár működött benne, és különböző kulturális intézmények is használták.

111 N. L.: Mitől „nőtt meg” a Pénzügyminisztérium. Magyar Nemzet 1948. október 19., 2. Rados Jenő (18951992) kortársa, Kotsis Iván pályájának emlékezetében így fogalmazott: „Az új pénzügyminisztérium erősen sérült és túl gazdag részletezésű neogót homlokzatára is kidolgoztam javaslatot. A problémát Rados Jenő és Meczner Lajos kartársaim megnyugtató módon oldották meg." Kotsis Iván: Életrajzom. S. a. r.: Prakfalvi Endre. H.A.P. könyvek 5. [Budapest 2010,] 251, 275.

112 Album 1908, 11. kép (mesternév nélkül), MNL, OL, K-487. 2. cs. fol. 669-670.

113 Az 1531-1848 között múködött Magyar Kamara elnökeinek 34 portréból álló galériááaból az Album XXII. fényképtábláján a következők láthatók: Hetesi Pethe László (1612-1617), Horváth Gáspár (1619-1624), Pálffy Pál (1625-1646), Lippay Gáspár (1646-1652), Majthényi Mihály (1655), gróf Niczky Kristóf (1782-1783), gróf Balassa Ferenc (1783-1785), Szécsen Sándor (1790-1808), Semsey András (1808-1814), gróf Majláth József (1813-1815).

114 Album 1908, 16., 17. kép

115 BFL, É. ü. t. (1. 11. j.) 540. doboz. Magy. Kir. Pénzügyministerium, A-B metszet, Fellner Sándor építész irodájából 1901. július 9-én Fellner Sándor építész kj, Majorossy Géza építőmester kj. Ép. eng.: 52468/1901-III, 1901. augusztus 6. Fol. 14.: Földszint alaprajza; fol. 19.: A-B metszet; fol. 21.: I-K hosszmetszet; fol. 35.: Felvonóterv. Album 1908, IV., X., XI. t., 9. kép (p. 5), 20. kép (p. 21). BFL, É. ü. t. (1. 11. j.) 541. doboz, fol. 114. Magy. Pénzügyminisztérium székház-helyreállítása, 1947. XII. 5., tervező Dr. Rados Jenő. Ép. eng.: 10876/1948/III. A „Földszinti alaprajz" című tervlapon található $\mathrm{A}-\mathrm{A}$ metszet.

116 A bika- vagy ökörfejes motívumot az Attila kincsének tartott nagyszentmiklósi lelet ivóedényeiről kölcsönözték, és számos korabeli épületen nyert alkalmazást. Album 1908, XIX. t. Mendöl Zsuzsanna: A Zsolnaygyárban készült kerámia közkutak. Janus Pannonius Múzeum Évkönyve XXVIII. 1983. Pécs 1984, 333., 16. j. Fellner Pénzügyminisztérium, ökörfejes vízköpő, 9. sz. terrakotta fazonkönyv; 2854, 1904. 
117 Az ÉB 1902. IX. 24-én engedélyezte Majorossynak, hogy az utcai homlokzatokon a "sajtolt téglával burkolt" felületek kivételével „dunai rostált homokból” készüljön a vakolat (50 fillér ráfizetéssel $\mathrm{m}^{2}$-enként), s hasonló feltételekkel lesz majd készítendő az irattár három legfelső emelete is. MNL, OL, K-487. 6. cs. E. N.

118 Album 1908, 23., 23. kép

119 Album 1908, 3., 4. kép

120 Album 1908, 8. A közéletet szolgálja ez az új palota: „Különleges czéljainak megfelel alaprajzi beosztása, középület jellegét, fontosságát, művészeti szerepét kiképzésén tükrözhettem vissza", de maga az építtetô minisztérium is "súlyt helyezett arra... hogy a vár, mint a főváros egyik leglassabban fejlődő része monumentális épülethez jusson" - summázta Fellner a végeredményt. Apró betűs lábjegyzettel zár: „A történelmi részre vonatkozó kutatásaimban dr. Csánki Dezső és Némethy Lajos urak voltak szívesek támogatni."

121 Pesti Hírlap LIV. 1932. X. 16. 9. Kézdi-Kovács László: Emlékezzünk régiekről! Jubiláris tárlat a Nemzeti Szalon- ban. A kiállítást a belvárosi Eötvös József Reáliskola jubileuma alkalmából rendezték. Az építészeket Alpár Ignáctól V. Quittner Zsigmondon át Wellisch Alfrédig bezárólag számosan képviselték. Lechner Jenő a Pénzügyminisztérium épületét „,angol gótikájú"'-nak minősítette, az Igazságügyit „empire ízlésü"-nek. Lechner Jenō: Eklektikus szellemü építőmúvészetünk az utolsó 50 évben. In: Az 50 éves Vállalkozók Lapja Jubileumi Albuma. Szerk.: Lakatos Mihály - Mészáros L. Edgár - Óriás Zoltán. [Budapest 1929,] 107-114.

122 Ujság XIV. 1938. I. 16. 17. A Kozma utcai izraelita temetőben (3j parcella 80. sora) Fellner saját maga tervezte síremlékén csupán korán elhunyt (1907) felesége, Goldstein Ida neve olvasható. A síremlék a Pénzügyminisztérium épületének gótizáló formavilágával tart kapcsolatot, a felirat fölött megjelenik a nemesi címer toronycsúcs és páncélos vitéz alakjával.

Köszönettel tartozom Bazsó Gábornak, aki a baráti és a kollegiális támogatást meghaladó módon segítette a kézirat elkészültét.

\section{THE PALACE OF THE FORMER HUNGARIAN ROYAL MINISTRY OF FINANCE IN THE CASTLE OF BUDA}

In the Austro-Hungarian Monarchy financial affairs remained the sovereign right of the Hungarian Kingdom. In the decades after the Compromise (1867) the finance ministry functioned at several separate venues in Buda Castle. Without calling a plan competition, finance minister László Lukács commissioned architect Sándor Fellner (1857-1944) to design a building complex that would house the entire ministry, and 4 million crowns were earmarked in article XXXIV of 1900 for the construction. The sketches submitted by Fellner, who started his studies in the forerunner of the Budapest Technical University and completed them in Vienna and Paris, were approved on the very last day of the 19th century. In terms of function, the design adopted the cell model, providing each official a room of his own. The rooms were separated and only accessible from lateral corridors. The most attractive appearance was given to the wing with the main staircase and state-room in Szentháromság square. The pair of towers flanking the projecting central section were crowned by roofs adopting the outline of the gothic tower cap of Maria am Gestade in Vienna. The brass knights on the pinnacles also reminded of the Rathausmann of the imperial city. The first section of the lateral wing in Hess András square contained the minister's suite of rooms, the wing across from it in Országház street included the secretary of state's offices and representative rooms. The ceremony of laying the foundation stone was held in spring 1901 and the capping celebration was on 19 September 1902, the centenary of Lajos Kossuth's birth. (Female day-wage labourers got 2 crowns bonus, the chief master builder received 1500 crowns.) The palace, which caused controversy among contemporaries as well (Wasn't it in conflict on ac- count of its volume and forms with the architecture of the Matthias Church, the church of coronations, renovated by Frigyes Schulek?) could be occupied in late 1904. In terms of innovation and engineering, the archival wing was outstanding, a witness of early Hungarian concrete iron constructions documented by sources. Built with great craftsmanship and abounding in splendid details - equipped lavishly with materials and products from all over historical Hungary - the palace, which represented its status well, was badly damaged in the siege of Buda in 1944/45 (Festung Budapest). The architect, whose active career of sixty years was acknowledged by his admission to the Incorporated Architects \& Surveyors (London) in 1937, did not live to see the crumbling of the walls. The monument he had designed in the Jewish cemetery in Kozma street only features his wife's name who died young (1907). The new looks of his building resulted from the reconstruction led by Jenő Rados (19471950). A contemporary critic with the fresh outlook of the new era declared that the resulting simplified form, particularly of the main façade, turned the former Finance Ministry into a truly monumental building.

PRAKFALVI Endre Forster Gyula Nemzeti Örökségvédelmi és Vagyongazdálkodási Központ / Gyula Forster National Centre for Cultural Heritage Management, Budapest

Kulcsszavak: Fellner Sándor, pénzügyminisztérium, historizmus, vasbetonszerkezet / Keywords: Sándor Fellner, Hungarian Royal Ministry of Finance, historicism, concrete iron constructions 